\title{
Cell-free DNA and next-generation sequencing in the service of personalized medicine for lung cancer
}

\author{
Catherine W. Bennett ${ }^{1}$, Guy Berchem ${ }^{1,2}$, Yeoun Jin Kim ${ }^{1}$ and Victoria El-Khoury ${ }^{1}$ \\ ${ }^{1}$ Department of Oncology, Luxembourg Institute of Health, L-1526 Luxembourg, Luxembourg \\ ${ }^{2}$ Centre Hospitalier de Luxembourg, L-1210 Luxembourg, Luxembourg \\ Correspondence to: Victoria El-Khoury, email: victoria.elkhoury@lih.lu \\ Keywords: lung cancer, cell-free DNA, next-generation sequencing, personalized medicine, biomarkers \\ Received: March 14, $2016 \quad$ Accepted: August 11, $2016 \quad$ Published: August 30, 2016
}

\section{ABSTRACT}

Personalized medicine has emerged as the future of cancer care to ensure that patients receive individualized treatment specific to their needs. In order to provide such care, molecular techniques that enable oncologists to diagnose, treat, and monitor tumors are necessary. In the field of lung cancer, cell free DNA (cfDNA) shows great potential as a less invasive liquid biopsy technique, and next-generation sequencing (NGS) is a promising tool for analysis of tumor mutations. In this review, we outline the evolution of cfDNA and NGS and discuss the progress of using them in a clinical setting for patients with lung cancer. We also present an analysis of the role of cfDNA as a liquid biopsy technique and NGS as an analytical tool in studying EGFR and MET, two frequently mutated genes in lung cancer. Ultimately, we hope that using cfDNA and NGS for cancer diagnosis and treatment will become standard for patients with lung cancer and across the field of oncology.

\section{INTRODUCTION}

Lung cancer is a leading cause of death worldwide, accounting for an estimated 1.6 million cancer deaths in 2013 [1]. In addition, lung cancer treatment is expensive and is the most expensive cancer type in Europe, costing 18.8 billion euros out of the 126 billion euros spent on cancer in 2009 and $\$ 12$ billion in the United States in 2010 $[2,3]$. As stated by Dr. Leonard Saltz at the 2015 annual meeting of the American Society of Clinical Oncology, new immunotherapies are even expected to drastically raise the cost of lung cancer treatments. Several types of lung cancer exist, including non-small cell lung cancer (NSCLC) and small cell lung cancer (SCLC). NSCLC accounts for $80-85 \%$ of lung cancer cases and can be further classified into three subtypes: squamous cell carcinoma, adenocarcinoma, and large cell carcinoma, while SCLC accounts for $15-20 \%$ of lung cancer cases [4]. Finally, tobacco smoking continues to be a significant risk factor in developing lung cancer, especially squamous cell carcinoma [5].

With the advent of advanced molecular techniques for diagnosing and treating diseases, personalized, or precision, medicine has emerged as a popular topic in the medical field. In personalized medicine, physicians use standard pathology information combined with molecular information to diagnose diseases and prescribe treatments catered to individual patient's needs [6]. Within the field of oncology, personalized medicine is at the forefront of cancer diagnosis and treatment. For example, cancerspecific biomarkers can be used to diagnose different cancer types [7]. In addition, mutational profiles of tumors can guide treatment options and help detect resistance to treatments, enabling physicians to evaluate therapeutic options quickly and effectively [8]. Lastly, proactive application of personalized medicine can be preventative by providing methods for detecting cancer risk factors and lessening them [9].

In the field of lung cancer research, personalized medicine has the potential to play a large role in diagnosing lung cancer and prescribing therapy. The ability to extract nucleic acids from tumor samples and detect mutations enables physicians to have access to large amounts of detailed genetic information. For instance, $E G F R$ and $A L K$ have been identified as key biomarkers in lung cancer, and molecular tests for $E G F R$ and $A L K$ have become common in lung cancer treatment [10]. If a patient tests positive for either of these mutations, lung cancer-specific tyrosine kinase inhibitors (TKIs) such as erlotinib, gefitinib, or crizotinib are prescribed $[10,11]$. Two of the most important advancements in personalized medicine, especially in the field of lung cancer, include the 
Table 1: Comparison of NGS panels and library preparation kits.

\begin{tabular}{|c|c|c|c|c|c|c|}
\hline & $\underset{\text { Input }}{\text { Minimum DNA }}$ & Sample Types & $\begin{array}{c}\text { Content and } \\
\text { targets }\end{array}$ & $\begin{array}{c}\text { Target or } \\
\text { Amplicon Size }\end{array}$ & $\begin{array}{c}\text { Library } \\
\text { Preparation } \\
\text { Time } \\
\end{array}$ & Cost \\
\hline $\begin{array}{l}\text { Illumina TruSeq }{ }^{\circledR} \\
\text { Amplicon Cancer } \\
\text { Panel }\end{array}$ & $\begin{array}{l}150 \mathrm{ng} \\
250 \mathrm{ng}\end{array}$ & $\begin{array}{l}\text { High quality gDNA, } \\
\text { FFPE }\end{array}$ & $\begin{array}{l}212 \text { amplicons for } \\
48 \text { genes }\end{array}$ & $170-190 \mathrm{bp}$ & $\begin{array}{l}\text { Fewer than } 7 \\
\text { hours }\end{array}$ & $\begin{array}{l}11,769 \text { euros } \\
(\$ 13,428) \text { for } 96 \\
\text { samples }\end{array}$ \\
\hline $\begin{array}{l}\text { Illumina TruSeq }{ }^{\circledR} \\
\text { Custom Amplicon } \\
\text { v1.5 }\end{array}$ & $50 \mathrm{ng}$ & Fresh, frozen, or FFPE & $\begin{array}{l}\text { Up to } 1,536 \\
\text { amplicons (custom } \\
\text { number of } \\
\text { hotspots) }\end{array}$ & $\begin{array}{l}150,175,250, \text { and } \\
425 \mathrm{bp}\end{array}$ & 10 hours & $\begin{array}{l}\text { Dependent on } \\
\text { number of amplicons }\end{array}$ \\
\hline $\begin{array}{l}\text { Illumina TruSeq }{ }^{\circledR} \\
\text { Custom Amplicon } \\
\text { Low Input Library } \\
\text { Prep Kit }\end{array}$ & $\begin{array}{l}10-50 \mathrm{ng} \\
\text { (depending on } \\
\text { FFPE DNA } \\
\text { quality) }\end{array}$ & $\begin{array}{l}\text { Low input samples } \\
\text { FFPE }\end{array}$ & $\begin{array}{l}\text { Up to } 1,536 \\
\text { amplicons (custom } \\
\text { number of } \\
\text { hotspots) }\end{array}$ & $\begin{array}{l}150,175, \text { and } 250 \\
\text { bp }\end{array}$ & 6.5 hours & $\begin{array}{l}\text { Dependent on } \\
\text { number of amplicons }\end{array}$ \\
\hline 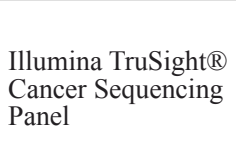 & $50 \mathrm{ng}$ & $\begin{array}{l}\text { gDNA } \\
\text { (FFPE compatibility } \\
\text { not supported) }\end{array}$ & $\begin{array}{l}\sim 4,000 \text { probes for } \\
1,700 \text { exons on } \\
94 \text { genes and } 284 \\
\text { SNPs }\end{array}$ & $\begin{array}{l}\text { Cumulative target } \\
\text { region: } 255 \mathrm{~kb} \text {. } \\
\text { Individual region } \\
\text { size enriched: } 350- \\
650 \mathrm{bp}\end{array}$ & 1.5 days & $\begin{array}{l}\text { Dependent on } \\
\text { number of targets }\end{array}$ \\
\hline $\begin{array}{l}\text { Illumina TruSight }{ }^{\circledR} \\
\text { Tumor } 15\end{array}$ & $20 \mathrm{ng}$ & FFPE & $\begin{array}{l}250 \text { amplicons for } \\
15 \text { genes }\end{array}$ & $\begin{array}{l}\sim 150-175 \text { bp on } \\
\text { average }\end{array}$ & 7 hours & $\begin{array}{l}2,354 \text { euros }(\$ 2,686) \\
\text { for } 24 \text { samples }\end{array}$ \\
\hline $\begin{array}{l}\text { Illumina TruSight }{ }^{\circledR} \\
\text { Tumor } 26\end{array}$ & $\begin{array}{l}30-300 \mathrm{ng} \\
\text { (depending on } \\
\text { FFPE DNA } \\
\text { quality) }\end{array}$ & FFPE & $\begin{array}{l}174 \text { amplicons for } \\
26 \text { genes }\end{array}$ & $165-195 \mathrm{bp}$ & $\begin{array}{l}\text { Fewer than } 7 \\
\text { hours }\end{array}$ & $\begin{array}{l}5,885 \text { euros }(\$ 6,715) \\
\text { for } 48 \text { samples }\end{array}$ \\
\hline $\begin{array}{l}\text { Ion AmpliSeq } \\
\text { Cancer Hotspot } \\
\text { Panel v2 (with } \\
\text { primer pool) }\end{array}$ & $10 \mathrm{ng}$ & $\begin{array}{l}\text { FFPE and Fine Needle } \\
\text { Aspirates (FNA) } \\
\text { (among others) }\end{array}$ & $\begin{array}{l}207 \text { amplicons for } \\
50 \text { genes }\end{array}$ & $111-187 \mathrm{bp}$ & 3.5 hours & $\begin{array}{l}\text { Ion AmpliSeq } \\
\text { Cancer Hotspot Panel } \\
\text { v2: } 216 \text { euros (\$246) } \\
\text { for } 8 \text { reactions } \\
\text { Ion AmpliSeq } \\
\text { Library kit } 2.0: 860 \\
\text { euros }(\$ 980) \text { for } 8 \\
\text { reactions }\end{array}$ \\
\hline $\begin{array}{l}\text { Ion AmpliSeq }{ }^{\mathrm{TM}} \\
\text { Comprehensive } \\
\text { Cancer Panel }\end{array}$ & $40 \mathrm{ng}$ & $\begin{array}{l}\text { FFPE and Fine Needle } \\
\text { Aspirates (FNA) } \\
\text { (among others) }\end{array}$ & $\begin{array}{l}16,000 \text { amplicons } \\
\text { for more than } 400 \\
\text { genes }\end{array}$ & $125-175 \mathrm{bp}$ & 3.5 hours & $\begin{array}{l}860 \text { euros }(\$ 980) \text { for } \\
8 \text { reactions }\end{array}$ \\
\hline $\begin{array}{l}\text { Roche GS FLX } \\
\text { Titanium Rapid } \\
\text { Library Preparation } \\
\text { Kit }\end{array}$ & $500 \mathrm{ng}$ & Double stranded DNA & N/A & $\begin{array}{l}3 \mathrm{~kb}, 8 \mathrm{~kb} \text {, or } 20 \mathrm{~kb} \\
\text { inserts }\end{array}$ & Not available & $\begin{array}{l}\$ 1,192 \text { for } 12 \text { library } \\
\text { preparations }\end{array}$ \\
\hline
\end{tabular}

Information from data sheets, communications, and websites from Illumina, Ion Torrent ${ }^{\mathrm{TM}}$, and Roche.

use of circulating cell-free DNA (cfDNA) as a diagnostic and prognostic biomarker and next-generation sequencing (NGS) for mutational analysis of lung tumors. The importance of these tools is reflected in the increase in publications regarding cfDNA and NGS over the past five years (Figure 1). In this review, we present both of these innovations and their utility in diagnosing and treating lung cancer.

\section{CELL-FREE DNA}

\section{cfDNA overview}

Discovered in 1948, cell-free DNA (cfDNA) circulating in blood has emerged as a promising diagnostic tool for patients with cancer [12]. While the total amount of cfDNA in the plasma and serum of cancer patients varies from patient to patient, patients with cancer have higher average plasma and serum levels of cfDNA than patients without cancer [13-15]. In patients with lung cancer, plasma cfDNA levels are higher in later stage patients (mean: $38 \mathrm{ng} / \mathrm{mL}, 95 \%$ confidence interval (CI): 26-56 ng/mL) than in earlier stage patients (mean: $23 \mathrm{ng} /$ $\mathrm{mL}, 95 \% \mathrm{CI}: 18-30 \mathrm{ng} / \mathrm{mL}$ ), and levels of plasma cfDNA over $100 \mathrm{ng} / \mathrm{mL}$ are more likely to be found in patients with SCLC versus NSCLC [15].

Several hypotheses exist for the release of tumor DNA into the bloodstream, the most accepted being via apoptotic and necrotic tumor cells or by active DNA release by tumor cells (Figure 2) [14, 16]. According to the hypothesis that cfDNA is released during apoptosis or 
necrosis, as tumor cells divide, the apoptotic and necrotic tumor cells and DNA strands that are not phagocytosed enter the bloodstream as cfDNA [14]. Furthermore, in support of this hypothesis, cfDNA strands seen in the bloodstream are similar in length to the 180 base pair DNA strands that are characteristic of apoptosis [14, 16, 17]. More recent data suggest that cfDNA does not enter the bloodstream through apoptosis or necrosis but is actively released by cancer cells as a signaling molecule [18].

Indeed, cfDNA has been shown to have characteristics of a signaling molecule that induces metastasis of tumor cells. First, Garci-Olmo et al. showed that murine NIH-3T3 cells incubated with plasma from human colorectal cancer subjects positive for KRAS mutations developed $K R A S$ mutations, and when these NIH-3T3 cells were injected into mice, tumors appeared, and human KRAS mutations were detected in mouse plasma [19]. Likewise, Trejo-Becerril et al. demonstrated that NIH-3T3 cells exposed to DNA from KRAS mutationpositive patient serum or cell supernatant developed a $K R A S$ mutation over time, and when $K R A S$-positive cells plus the colon cancer carcinogen 1,2-dimethylhydrazine were injected into rats, the rats developed tumors with detectable KRAS mutations [20]. Taken together these studies suggest that a likely role for cfDNA is to act as a signaling molecule in tumor metastasis.

\section{Clinical potential of efDNA in oncology}

While the exact role of cfDNA remains elusive, it has clinical potential for detecting cancer, monitoring tumor mutations, and determining the effectiveness of treatment. In terms of cancer diagnosis, increased levels of cfDNA can be used as an indication of cancer across tumor types [21-24]. Not only can levels of cfDNA be used to distinguish cancer patients from non-cancer patients, but genomic analysis of cfDNA can also reveal known tumor mutations. To determine if cfDNA could be a reliable source for cancer mutation analysis, Lebofsky et al. compared the mutational status of plasma cfDNA samples to solid biopsy samples from 34 patients with metastatic cancer. In 27 of these patients, 28 out of 29 total mutations found in solid biopsy samples were also found in plasma cfDNA [25]. Similarly, when Janku et al. compared the mutational status of $B R A F, E G F R, K R A S$, and $P I K 3 C A$ in plasma cfDNA samples to biopsy tissue samples, most mutations that were detected in the tumor biopsy samples were detected in plasma cfDNA samples: the concordant cases reached $91 \%$ for $B R A F$ mutations, 99\% for EGFR mutations, $83 \%$ for KRAS mutations, and 91\% for PIK3CA mutations [26].

In addition to cfDNA found in plasma and serum, cfDNA in urine has shown promise as a biomarker for certain cancers. For example, in patients with non-muscleinvasive bladder cancer, high levels of cfDNA were found in urine samples in patients with progressive disease, including in samples from patients where levels of cfDNA were low in plasma [27]. Moreover, in a genomic analysis of urine cfDNA in patients with urothelial bladder cancer, there was a high rate of concordance between mutations found in urine cfDNA and tumor tissue. Importantly, circulating tumor DNA in urine had a sensitivity rate of $90 \%$ and permitted a better detection of genetic aberrations than urinary cellular DNA [28]. Taken together, these results indicate that urine cfDNA has a clinical utility for patients with cancer, especially as a minimally-invasive liquid biopsy technique.

Finally, cfDNA could be used to track response to treatment over time. In a study conducted to test this possibility, Frenel et al. tracked the mutational status of 39 late stage cancer patients over 11 months. At inclusion, 44 total mutations were detected in plasma cfDNA samples of 23 out of 39 patients, and at later time-points, four
A.

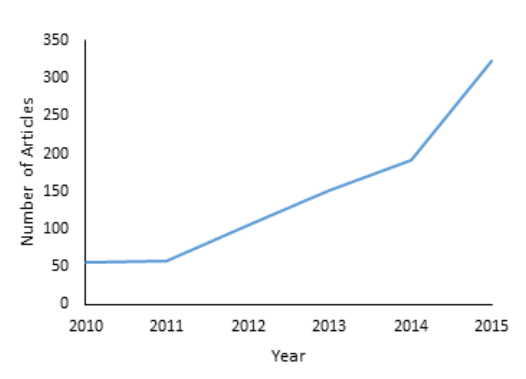

B.

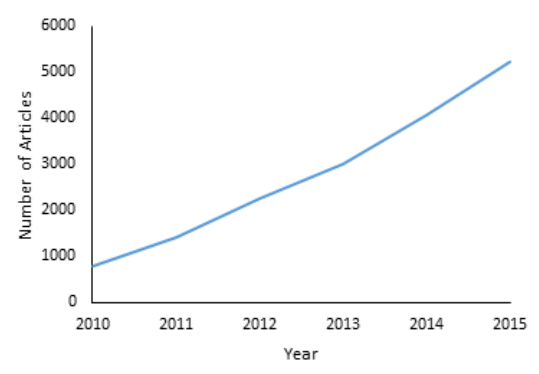

C.

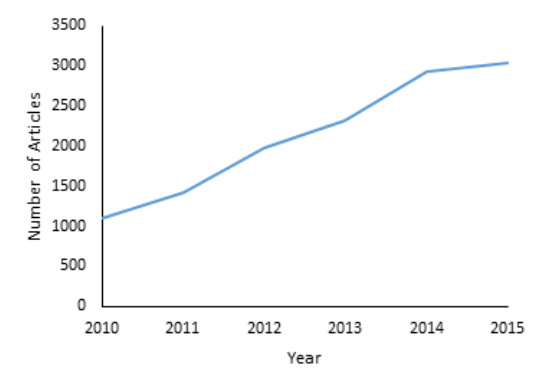

Figure 1: Rise of publications in cell-free DNA, next-generation sequencing, and personalized medicine. A. Increase in publications regarding cell-free DNA from 2010 until 2015. Number of articles determined by Pubmed search of "cell-free DNA" OR "circulating free DNA." B. Increase in publications regarding next-generation sequencing from 2010 until 2015. Number of articles determined by Pubmed search of "next-generation sequencing" OR "high-throughput sequencing." C. Increase in publications regarding personalized medicine from 2010 until 2015. Number of articles determined by Pubmed search of "personalized medicine" OR "precision medicine." 
more plasma cfDNA samples harbored mutations [29]. Additionally, in plasma cfDNA from patients who were given targeted therapies, four patients exhibited a mutation allele frequency decrease, and two patients showed a mutation allele increase, indicating that mutations in cfDNA can be helpful in determining a patient's response to treatment [29]. Therefore, cfDNA is a viable clinical tool for tracking changes in tumor mutations and responses during treatment.

\section{cfDNA and lung cancer}

For patients with lung cancer, cfDNA could be used as a diagnostic tool. In terms of diagnosis, plasma concentration of total cfDNA can serve as a biomarker for patients with lung cancer as patients with NSCLC have higher plasma cfDNA concentrations than healthy patients. Patients who were followed and did not relapse had lower plasma concentrations of cfDNA than patients who did relapse $[21,30]$. These findings indicate that plasma cfDNA levels may aid in providing a diagnosis of NSCLC and in following tumor status over time. In addition, determining single nucleotide variants (SNVs) present in cfDNA samples could be useful for diagnosing lung cancer. In a pilot study using four patients with earlystage NSCLC, 16 SNVs were detected in cfDNA samples, and only one cfDNA sample bore $90 \%$ of the variants detected, while $22 \%$ and $33 \%$ of the variants found in the three other tumor samples were also found in cfDNA [31]. These results indicate that analysis of SNVs in cfDNA could have potential for diagnosing lung cancer in early- stage patients but that technological improvements are needed to increase the sensitivities of the assays. Finally, given that several inflammatory lung conditions increase plasma cfDNA levels, differentiating between patients with lung cancer and these conditions is an important diagnostic consideration. To that end, Szpechcinski et al. found that levels of plasma cfDNA were the highest in NSCLC patients and were significantly higher than plasma cfDNA levels in patients with inflammatory lung conditions (asthma, chronic obstructive pulmonary disease, and sarcoidosis) or healthy control patients [32].

While levels of cfDNA could serve as a diagnostic tool, the role of cfDNA levels as an indication of therapy effectiveness remains unclear. An early report suggested that NSCLC patients who progressed after chemotherapy had higher levels of plasma cfDNA than patients who did not progress and that patients who responded positively to chemotherapy had lower levels of serum cfDNA [33]. Additionally, in a study conducted with stage I NSCLC patients treated with stereotactic body radiotherapy, higher plasma cfDNA levels were found in patients who relapsed than in patients who had a positive response to therapy [34]. In contrast, a more recent report found that there is no correlation between levels of plasma cfDNA and response to platinum-based chemotherapy in patients with NSCLC [35]. Moreover, a report that examined the effects of several types of treatment (chemotherapy and tyrosine kinase inhibitors) on levels of plasma cfDNA found that there is no correlation between total plasma cfDNA levels and tumor prognosis in patients with late-stage NSCLC [36]. While these studies suggest that cfDNA levels may not be viable for monitoring response to treatment, they

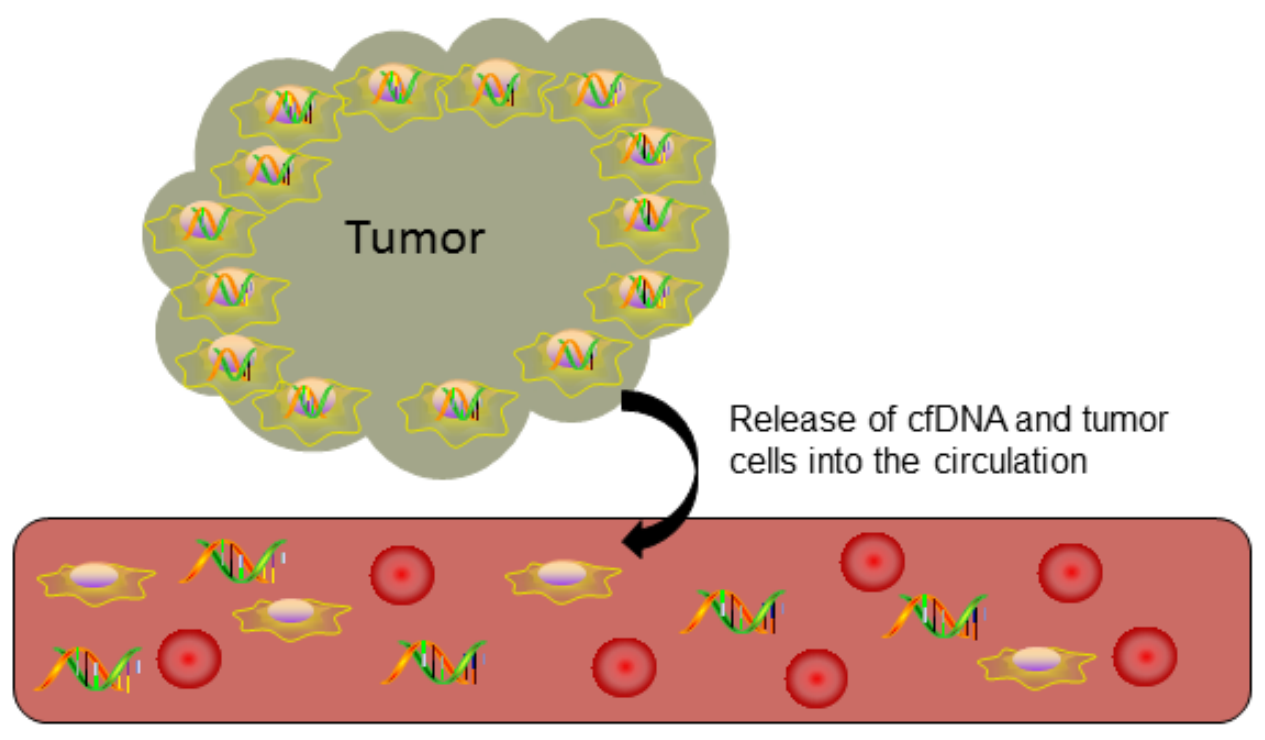

Figure 2: Release of cell-free DNA into circulation. Cell-free DNA enters the bloodstream after apoptosis or necrosis or through active secretion by tumor cells. 
do not preclude the usefulness of analyzing tumor-specific mutations in cfDNA.

In order to determine if the emergence of somatic mutations indicating therapeutic resistance (resistance mutations) can be detected in cfDNA, Del Re et al. used droplet digital PCR (ddPCR) to analyze cfDNA samples from patients who had previously been treated with EGFR-TKIs. Resistance mutations were detected in $27 / 33$ samples, including 11 samples with the T790M $E G F R$ mutation, three samples with a mutation in $K R A S$, and 13 samples with both mutations [37]. In eight cases, tumor biopsies conducted after treatment were available, and there were $62.5 \%$ and $37.5 \%$ concordance rates for $E G F R$ and KRAS, respectively [37]. Therefore, analysis of mutations in cfDNA, rather than levels of cfDNA, could provide insights into treatment effectiveness.

Finally, to evaluate the usefulness of cfDNA for the detection of epigenetic modifications in lung cancer, Lee et al. analyzed the methylation of TMEFF2 in serum cfDNA samples from patients with NSCLC. They found TMEFF 2 methylation in 29/316 samples and no TMEFF2 methylation in control samples, and when compared to corresponding solid tumor samples, three serum cfDNA samples matched tumor DNA samples [38]. Also, a study by Wang et al. found that increased $A P C$ and $R A S S F 1 A$ methylation levels in plasma cfDNA 24 hours post chemotherapy were correlated with a positive response to treatment in patients with advanced lung cancer [39]. In addition, in a study conducted to determine the methylation status of the DCLK1 promoter in plasma cfDNA from lung cancer patients across stages, $49.2 \%$ of plasma cfDNA samples were methylated [40]. Notably in this study, $73.7 \%$ and $39.1 \%$ of SCLC and NSCLC samples respectively exhibited $D C L K 1$ plasma cfDNA methylation [40]. Taken with the results of Fournié et al. [15], these results indicate that cfDNA levels and methylation status could be used to aid in differentiating between SCLC and NSCLC diagnosis. Lastly, cfDNA methylation has the potential to differentiate lung cancer from other inflammatory lung diseases. To address this, Wielscher et al. found methylation levels of HOXD10, PAX9, PTPRN2, and $S T A G 3$ to be higher in serum and plasma cfDNA samples from lung cancer patients than in patients with interstitial lung disease and chronic obstructive pulmonary disease [41]. In light of these results, the epigenetic status of plasma cfDNA is a promising biomarker for detecting lung cancer or a risk of lung cancer.

\section{Challenges presented by using cfDNA in routine clinical practice}

cfDNA is undoubtedly a promising non-invasive biomarker, and analysis of cfDNA can support personalized medicine for cancer patients. Nevertheless, many issues must be addressed before it is widely accepted as a biomarker in clinical practice. First, technical challenges should be overcome, including (1) optimization of the protocols at the pre-analytical (sample collection, processing and storage), analytical (cfDNA isolation, quantification and mutational analysis) and post-analytical (data processing and interpretation) levels, (2) standardization of the operating procedures and (3) data validation in large multicenter studies [42]. Next, a deep and mature knowledge of cfDNA origin and clinical significance may facilitate the adoption of cfDNA as a liquid biopsy in clinics. Furthermore, a consistent detection of mutations in cfDNA, regardless of tumor stage, is an important step toward widespread physician approval of using cfDNA as a liquid biopsy. This can be achieved through combined improvements in the technical procedures for cfDNA isolation and an increase in the sensitivity of the genomic approaches for cfDNA analysis. Moreover, the validation of cfDNA assays for clinical diagnostics must meet the Clinical Laboratory Improvement Amendments (CLIA) requirements for the analytical and clinical performances of the test [43]. Also, if cfDNA analysis is going to be performed by nextgeneration sequencing, these sequencing platforms must be validated for clinical use [44]. Additionally, the NGS assay itself must be validated for cfDNA analysis, and the control used for validation should mimic the fragmented human cfDNA. Finally, standardized clinical guidelines need to be established, understood, and followed by the clinical team.

\section{NEXT-GENERATION SEQUENCING}

\section{NGS overview}

Next-generation sequencing (NGS) has emerged in the past decade as an efficient method for sequencing DNA and obtaining genetic information. Compared to the first generation sequencing method, Sanger sequencing, NGS is more efficient, more sensitive, and is becoming less expensive [45]. Indeed, the most obvious advantage of NGS over other techniques is the massively parallel sequencing feature. In a routine clinical setting, this property is important when several patients' samples and different genomic regions have to be processed and data generated quickly. Another noteworthy advantage of NGS technology when compared to Sanger sequencing is its compatibility with low-quantity input DNA, as it is often the case with archived clinical samples. Moreover, its high sensitivity and reliability enable a more accurate detection of clinically important mutations. Finally, when multiple targets have to be analyzed, NGS technology considerably reduces the cost of screening compared to analysis with a lower throughput technology [44]. Despite the tremendous advantages of NGS, some challenges 
and considerations have to be taken into account for its complete implementation in a clinical setting. These issues are discussed in different sections of the present review.

The basic workflow of NGS is as follows: library preparation, library amplification, sequencing, and data analysis. While the workflow remains the same across platforms, the specific methods for library preparation and sequencing vary. Briefly, the Roche 454 and Ion Torrent ${ }^{\mathrm{TM}}$ platforms use emulsion PCR to collect single strands of DNA in each single bead, amplify DNA, and deposit amplified DNA on chips to be read by the sequencer [46, 47]. The Illumina platforms use a "cluster amplification" approach, whereby sample DNA is deposited on a flow cell and is amplified by bridge PCR [48]. To sequence, each company uses different technology to detect the addition of single nucleotides: luminescence (Roche), release of hydrogen ions (Ion Torrent ${ }^{\mathrm{TM}}$ ), and fluorescence (Illumina) [46-48]. In this way, whole genomes, exomes, transcriptomes, and targeted areas of the genome can be sequenced and mutations detected.

\section{NGS and lung cancer}

In personalized medicine, NGS has several important applications and is useful in cancer diagnosis and treatment. In a study to determine if results from NGS are useful for detecting mutations in tumor tissues, Hagemann et al. analyzed the mutations revealed from NGS from the five most common cancer types and calculated a Shannon entropy level for each tumor type to determine if NGS revealed new information. High levels of Shannon entropy indicate analytic utility, while low levels indicate that a variable provides no new or useful information [49]. In this study, Shannon entropy levels for these cancer types from highest to lowest were colorectal cancer, high grade glioma, non-small cell lung cancer, pancreatic cancer, and sarcomas/soft tissue tumors [49]. These results suggest that for some major cancer types, including lung cancer, NGS has analytic utility and could provide useful information in cancer diagnosis without being redundant.

In cancer research, NGS can be used to detect mutations in tumors that might not have been detected with Sanger sequencing. For instance, in a study to determine mutations in lung and colon adenocarcinomas, NGS revealed three novel KRAS and EGFR mutations [50]. In addition, targeted NGS has been used to characterize similar mutations across different tumor types. In particular, Schwaederle et al. used NGS with solid tumor samples to determine if certain mutations were common to squamous tumor types. They found a set of genes more commonly mutated in either squamous (TP53, PIK3CA, $C C N D 1$, CDKN2A, SOX2, NOTCH1, and FBXW7) or nonsquamous $(K R A S)$ tumors [51].

In two comprehensive studies by The Cancer Genome Atlas (TCGA) Research Network, whole genome sequencing was used to determine commonly mutated genes in 178 lung tumor samples from patients with squamous cell carcinoma and 230 lung tumor samples from patients with adenocarcinoma. From the study with squamous cell carcinoma, notable results include a high rate of copy number alterations in SOX2, PDGFRA, KIT, EGFR, FGFR1, WHSC1L1, CCND1, and CDKN2A; a total of 228 non-silent and 360 exonic mutations; the detection of significantly mutated genes, including TP53, CDKN2A, PTEN, PIK3CA, KEAP1, MLL2, HLA-A, NFE2L2, NOTCH1, and RB1; overexpression of SOX2 and TP63; inactivation of $C D K N 2 A$ in $72 \%$ of cases; and EGFR amplifications in 7\% of samples [52]. In addition, notable results from the study with adenocarcinoma include the identification of 18 genes that are commonly mutated in lung adenocarcinoma; determining somatic copy number alterations in NKX2-1, TERT, MDM2, KRAS, EGFR, MET, CCNE1, CCND1, TERC, MECOM, CCND3, and $C D K N 2 A$; the detection of $M E T$ exon 14 skipping; detecting mutations in $K R A S, E G F R, B R A F, E R B B 2$, and $M E T$ that lead to activation of the receptor tyrosine kinase pathways; and determining frequently mutated activated molecular pathways in lung adenocarcinoma, including the RTK/RAS/RAF pathway, PI3K-mTOR pathway, and p53 pathway [53]. These results provide an overview of mutations in lung squamous cell carcinoma and adenocarcinoma and a baseline for future studies.

Additionally, in order to elucidate the genetic differences between lung neuroendocrine tumors, including SCLC, large-cell neuroendocrine carcinoma (LCNEC), typical carcinoid (TC), and atypical carcinoid (AC), 70 neuroendocrine tumor samples were sequenced using targeted NGS. Overall, low-grade tumors (AC and TC) had fewer mutations than high grade tumors (SCLC and LCNEC), and the following genes were associated with specific tumor types: $J A K 3, N R A S, R B 1$, and VHL1 with SCLC; FGFR2 with LCNEC; KIT, PTEN, HNF1A, and $S M O$ with $\mathrm{AC}$; and SMAD4 with TC [54]. Likewise, in a study that examined the mutational status of tissue samples from patients with $\mathrm{AC}$ and $\mathrm{TC}$ using a targeted NGS panel, mutations (BRAF, SMAD4, PIK3CA, and $K R A S$ ) were only found in one out of 25 patients [55]. Taken together these two studies indicate that AC and TC tumors have distinct and fewer mutations than other pulmonary tumors with neuroendocrine features.

In other studies, NGS has been used to further characterize lung cancer mutations. First, Zhao et al. used their newly developed targeted NGS system to detect single nucleotide variants and indels in solid tumor samples of patients with lung cancer. One hundred and one mutations were found in a total of 168 genes, with $K R A S$, TP53, EGFR, PIK3CA, BRAF, NRAS, JAK3, CTNNB1, and $C K D N 2 A$ being the most often mutated genes [56]. Moreover, 23 deletions, including deletions in ARID4B and TP53 were detected [56]. Second, Iwakawa et al. performed whole exome sequencing and RNA sequencing 
on solid tumor samples from patients with SCLC. TP53, $R B 1$, and $P T E N$ were found to be highly mutated in both primary and metastatic SCLC tumors, and of these genes, TP53 and RB1 were found from tumors across stages, while PTEN was only found in tumors from stages II-IV [57].

Also, several gene fusions in lung cancer have been detected using NGS. For example, in NSCLC samples, simultaneous detection of $A L K, R O S 1$ and $R E T$ fusions and somatic mutations could be achieved in a very sensitive, specific, and tissue-sparing way using targeted NGS [58]. Similarly, a FGFR3-TACC3 fusion was detected in a solid tumor sample from a patient with NSCLC for whom no other oncogenic mutations had been found using reverse transcription PCR, and this fusion was then detected in two more tumor samples that were thought to harbor no oncogenic mutations [59]. Of note, exome sequencing identified a germline mutation in PARK2 that was associated with familial lung cancer [60]. In another study that considered the role of NGS in determining the inherited mutations of lung cancer, mutations were found in the CLTCL1 and PDE4DIP genes in whole blood samples of family members with NSCLC [61].

Altogether, data from these studies demonstrate the utility of NGS in finding mutations in lung cancer and the ability to use NGS as a diagnostic tool for patients with lung cancer. Moreover, they suggest that NGS could be used to determine the genetic susceptibility for this disease.

\section{NGS and biopsy types}

Given the potential for using NGS in the diagnosis of lung cancer, finding a biopsy that would provide reliable diagnostic information and would be less invasive to obtain than lung tumor tissue has emerged as a focus in lung cancer research [62]. Possible biopsies include fine needle aspirates (FNA) from tumor tissue, cfDNA from plasma and serum, bronchoalveolar lavage and pleural fluid, and cfDNA from urine. First, fine needle aspirates (FNA) have shown some success with detecting lung cancer mutations using NGS. When compared to paired formalin-fixed, paraffin-embedded (FFPE) tumor tissues, FNA from patients with lung adenocarcinoma had 99.9\% overall sequence concordance, while only two single nucleotide polymorphisms from one patient were not detected in FNA tissue [63]. Also, when used to detect mutations in FNA samples from lung cancer metastatic specimens in lymph nodes, several mutations were found, including EGFR (34\%), KRAS (8\%), BRAF (3\%), PIK3CA (9\%), and TP53 (36\%) [64]. Therefore, NGS could be used with FNA tissue to detect lung cancer mutations in primary tumors and in metastatic sites.

Next, using NGS to find mutations in bodily fluids is possible due to the relative ease of collecting these samples. For instance, in a study to compare NGS results from plasma cfDNA and tumor samples using whole genome sequencing and targeted NGS, Xia et al. developed a plasma genomic abnormality (PGA) score to reflect mutational status and tumor burden. Patients with lung cancer had a higher plasma cfDNA concentration (4.9 ng per $400 \mu \mathrm{L}$, range $2.25-26.98 \mathrm{ng}$ per $400 \mu \mathrm{L}$ versus $2.32 \mathrm{ng}$ per $400 \mu \mathrm{L}$, range $1.30-2.81 \mathrm{ng}$ per $400 \mu \mathrm{L})$ and a higher PGA score (19.50, range 5.89-64.47 versus 9.28, range 7.38-11.08) than control patients, and targeted NGS revealed 14 point mutations in 12 genes in solid tumor tissue [65]. Also, to determine the mutations found in plasma and serum cfDNA samples of NSCLC patients, Paweletz et al. developed a targeted NGS panel for 11 oncogenes commonly associated with NSCLC. cfDNA samples were taken from patients with advanced NSCLC with known tumor genotypes. Mutations found in plasma cfDNA included $A L K, R O S 1$, and RET rearrangements, HER 2 insertions, and MET amplification, and mutations in $B R A F$ and KRAS [66]. The NGS results had sensitivities of $79 \%$ and $75 \%$ in the two subgroups of samples tested, and a specificity of $100 \%$ [66]. Moreover, two mutations that were not detected in tumor tissue were detected in cfDNA with the NGS assay (double deletion in exon 19 of EGFR in one patient and high levels of $M E T$ amplification in a different patient) and were confirmed with droplet digital PCR (ddPCR) and fluorescent in situ immunohistochemistry, respectively [66]. Furthermore, in a different study, there was a $76 \%$ concordance rate between mutations found in plasma cfDNA and mutations found in tumor samples from late-stage NSCLC patients, and additional mutations were found in cfDNA in several genes: EGFR, KRAS, PIK3CA, and TP53 [67]. Lastly, another study by Vanni et al. compared mutations found in plasma cfDNA samples to those found in solid tumor samples from 12 NSCLC patients from various stages using targeted NGS. In the solid tumor samples (FFPE and snap frozen), all EGFR and $K R A S$ mutations found with Sanger sequencing were also found using targeted NGS; however, in only one out of nine patients did the plasma cfDNA mutational profile match the solid tumor mutational profile [68].

It is noteworthy that the reported discrepancies may have occurred due to different assay sensitivities and to technical difficulties involved in handling low concentrations of DNA. Because levels of cfDNA are lower in early-stage patients, cfDNA samples in the Vanni et al. study might not have been concentrated enough to detect mutations. Moreover the NGS assay used in this study allowed the detection of mutations when the allele frequency was $\geq 5 \%$ [68], in contrast to the detection limit of $0.4 \%$ reported by Paweletz et al. [66]. Significant efforts have been undertaken to increase the sensitivity of cfDNA analysis [69-71], and these technological advances should be able to improve the current challenge associated with the accuracy of genotyping cfDNA. 
Besides plasma, other bodily fluids have shown promise for mutational analysis. For example, mutations in bronchoalveolar lavage (BAL) and pleural fluids have been tested with NGS and yielded promising results. When NGS was used to test $48 \mathrm{BAL}$ and pleural fluid samples for $E G F R$ mutations, $81 \%$ of samples tested positive for $E G F R$ mutations, compared to the $16 \%$ of samples that tested positive using Sanger sequencing [72].

Finally, given the relative ease of collecting urine samples, early data suggest that using NGS to determine mutations in urine cfDNA shows some promise for diagnosing lung cancer and monitoring response to treatment. For example, in TKI-pretreated patients with late stage NSCLC, the T790M mutation was found in $71 \%$ of urine cfDNA samples and in $75 \%$ of tissue samples, as assessed by the Trovagene quantitative PCR-NGS EGFR T790M assay and the Therascreen ${ }^{\mathbb{R}}$ EGFR RGQ polymerase chain reaction test, respectively. Importantly, when tumor tissue was used as a reference, $93 \%$ of T790M-positive patients were also positive for this mutation in cfDNA from urine samples $\geq 90 \mathrm{~mL}$. This percentage dropped to $72 \%$ when all urine volumes (from 10 to $100 \mathrm{~mL}$ ) were considered (Gadgeel et al., poster presented at 2015 AACR-NCI-EORTC International Conference). Furthermore, using a similar approach to detect the T790M resistance mutation, another group found that the sensitivity of cfDNA for the detection of the T790M mutation in urine was $100 \%$ when using the mutational status of the tissue as a reference. Interestingly, the T790M mutation could be detected in urine samples three months earlier than progression appeared on clinical radiographic scans (Husain et al., poster presented at 2015 ASCO Annual Meeting). Taken together, these studies highlight the importance of urine cfDNA and NGS to analyze mutations in patients with NSCLC. However, since the use of urinary cfDNA to detect and monitor lung cancer is very recent in the field of oncology, caution should be exercised when raising conclusions from the studies mentioned above, which should be considered as preliminary. Further large-scale studies are needed to more specifically characterize the use of NGS with urine samples for lung cancer management.

\section{Technical comparison of NGS library preparation kits}

Currently, Illumina, Life Technologies, and Roche 454 sequencing are the leading companies that dominate the NGS market. Both the Illumina and Ion Torrent ${ }^{\mathrm{TM}}$ (Life Technologies) platforms have several options for creating NGS libraries that are relevant in oncology (Table 1). First, hotspot panels enable targeted NGS for specific mutational cancer hotspots. In these panels, areas of genes that are often mutated in cancer are targeted and enriched using multiplex-PCR based library preparation
[73]. The technology used for the Ion Ampliseq ${ }^{\mathrm{TM}}$ (Life Technologies) and Truseq ${ }^{\circledR}$ Amplicon (Illumina) hotspot panels is based on this library preparation approach and enrichment. In the Illumina kits, there is also a prior targeted capture of the regions of interest by means of oligonucleotide probes. Illumina's TruSeq ${ }^{\circledR}$ Amplicon Cancer Panel targets 48 genes with 212 amplicons in order to detect somatic mutations in FFPE tumor samples. Other TruSeq $^{\circledR}$ panels include the TruSeq ${ }^{\circledR}$ Custom Amplicon v1.5 kit in which researchers can design custom panels with up to 1,536 amplicons per reaction with as little as 50 ng of input DNA. The TruSeq ${ }^{\circledR}$ Custom Amplicon Low Input Library Prep kit is particularly interesting for low input and FFPE samples because it requires as few as 10 ng of DNA per sample.

In order to determine the relevance of using NGS to detect mutations in cancer patients in routine clinical practice, Wong et al. used the Illumina TruSeq ${ }^{\circledR}$ Amplicon Cancer Panel to sequence tumors from 854 patients recruited in the multi-institutional Cancer 2015 cohort study [74]. Although the mutations found were successfully validated by the Agena MassARRAY ${ }^{\circledR}$ assay, this study reports several limitations, including not being able to sequence a number of patients' samples due to limited amount of starting material (less than 50 ng) and poor quality DNA samples that did not pass the sequencing quality-control filters [74]. These issues could be addressed through the use of panels or technologies that require lower input DNA and through the refinement and optimization of technical procedures, from tissue fixation to FFPE block storage. Given that the TruSeq ${ }^{\circledR}$ Custom Amplicon Low Input Library Prep kit is new, little data exist on its relevance in a clinical setting; however, given that it only requires $10 \mathrm{ng}$ of input DNA and that it is compatible with challenging samples like FFPE, it may be suitable for use with cfDNA samples in which DNA is fragmented and is found in limited quantities.

Other panels from Illumina include the TruSight ${ }^{\mathbb{B}}$ panels that target whole exons and noncoding regions of DNA as opposed to hotspot regions [75]. In cancer genomics, the TruSight ${ }^{\circledR}$ Cancer Sequencing Panel targets 94 genes that are thought to contribute to cancer and 284 single nucleotide polymorphisms (SNPs). In addition, the TruSight ${ }^{\circledR}$ Tumor 15 targets relevant regions in 15 genes that are often mutated in solid tumors, while the TruSight ${ }^{\circledR}$ Tumor 26 , the first commercially available small actionable gene panel, is designed to assess lowfrequency mutations in 26 genes involved in lung, gastric, colon, ovarian cancer and melanoma [75]. Both panels are compatible with FFPE samples. Importantly, the Illumina TruSight ${ }^{\mathbb{B}}$ Tumor 26 panel has been clinically validated and is currently proposed as a clinical test by several institutes and laboratories [75].

With Ion Torrent ${ }^{\mathrm{TM}}$ technology, several options are on the market for library preparation and targeted NGS. For example, the Ion AmpliSeq ${ }^{\mathrm{TM}}$ Cancer Panel v1 that 
covers 739 hotspot mutations in 46 genes and Panel v2 that covers 2855 hotspot mutations in 50 genes are used with the Ion AmpliSeq ${ }^{\mathrm{TM}}$ Library Kit 2.0 to generate a multiplex PCR-based library starting with only $10 \mathrm{ng}$ of DNA. Challenging samples such as FFPE tissues are compatible with these kits. The Ion AmpliSeq ${ }^{\mathrm{TM}}$ Cancer Hotspot Panel v2 has now been validated for clinical use in accordance with the Clinical Laboratory Improvement Amendments (CLIA) requirements [43, 75]. Given the low DNA input required for this panel and its possible use with fragmented DNA, it has the potential to be used with cfDNA. Accordingly, Life Technologies launched the Ion Torrent ${ }^{\mathrm{TM}}$ LiquidBiopsy ${ }^{\mathrm{TM}}$ Platform for simultaneous mutational analysis of cfDNA, circulating tumor cells, and white blood cells from a single blood sample (10 $\mathrm{mL}$ of blood) using the Ion AmpliSeq ${ }^{\mathrm{TM}}$ Cancer Hotspot Panel v2 for library construction and the Ion PGM system for sequencing. In addition to the Ion Torrent ${ }^{\mathrm{TM}}$ hotspot panels, Ion Torrent ${ }^{\mathrm{TM}}$ also produces the Ion AmpliSeq ${ }^{\mathrm{TM}}$ Comprehensive Cancer Panel that targets the exons of over 400 oncogenes and tumor suppressor genes. This panel is compatible with low integrity DNA such as FFPE but requires $40 \mathrm{ng}$ of starting DNA material that may prevent its use with cfDNA.

Finally, the Roche 454 platform has limited library preparation kits. The GS FLX Titanium Library Preparation kit requires $500 \mathrm{ng}$ of input DNA and can be used with $3 \mathrm{~kb}, 8 \mathrm{~kb}$, or $20 \mathrm{~kb}$ inserts. Given the large amount of DNA required for this kit, it is not relevant for detecting mutations in samples where there is a limited quantity of DNA (FFPE, cfDNA).

In addition to the solutions offered by Illumina and Life Technologies for sequencing cfDNA that are discussed above, different companies propose kits specifically designed to optimize library preparation and enrichment from low input, fragmented cfDNA. As claimed by the manufacturers, this is achieved through improvements in library yield and quality, particularly a higher conversion rate of DNA to sequencing-competent adaptor-linked fragments and uniform GC-unbiased sequence coverage of the original DNA sample. Some of these kits are even compatible with an amplification-free workflow in order to reduce GC bias. Below are the most relevant examples of library preparation kits for cfDNA sequencing.

First, the GeneRead ${ }^{\mathrm{TM}}$ DNA library I Core Kit, GeneRead $^{\mathrm{TM}}$ Adaptors, and the GeneRead ${ }^{\mathrm{TM}}$ DNA I Amp Kit from Qiagen can be used for DNA library preparation and subsequent sequencing on Illumina platforms, starting with 1 to $100 \mathrm{ng}$ of cfDNA. Next, Bioo Scientific $^{\circledR}$ has developed NEXTflex ${ }^{\mathrm{TM}}$ Cell Free DNASeq Kit, a library preparation kit for use with cfDNA on Illumina platforms. This kit requires only $1 \mathrm{ng}$ of cfDNA, and library preparation can be completed in only two hours. Additionally, Swift Biosciences ${ }^{\mathrm{TM}}$ offers different possibilities for constructing libraries compatible with
Illumina sequencing platforms, from only $10 \mathrm{ng}$ of cfDNA. For whole genome sequencing, the Accel-NGS ${ }^{\circledR} 2 \mathrm{~S}$ PCRFree DNA Library Kit is recommended. For targeted NGS, the Accel-Amplicon ${ }^{\mathrm{TM}}$ 56G Oncology Panel covers hotspots of 56 cancer-related genes using 263 amplicons and the Accel-Amplicon ${ }^{\text {TM }}$ EGFR Pathway Panel covers hotspots of $E G F R, N R A S, K R A S$ and $B R A F$ genes using 17 amplicons. Moreover, New England Biolabs offers kits for library construction from challenging samples that are compatible with Illumina sequencing. Their newly released NEBNext Ultra II DNA Library Prep Kit is an improved version of the original NEBNext Ultra Kit and is amenable to library construction from as little as $500 \mathrm{pg}$ of input FFPE DNA. This kit has been successfully used for cfDNA mutational analysis (communication by Dr. Christopher Smith, Post-Doctoral Research Associate at the Cancer Research UK, Cambridge Institute, in October 2015 to New England Biolabs). In April 2016, New England Biolabs released the NEBNext Direct Cancer HotSpot Panel kit, which relies on the hybridizationbased capture method. This kit enables DNA enrichment from 190 targets in 50 cancer-related genes starting with as few as $10 \mathrm{ng}$ of DNA and is suitable for use with cfDNA and FFPE samples. Furthermore, the ThruPLEX ${ }^{\mathrm{TM}}$ Plasma-seq kit from Rubicon Genomics enables library preparation from 1 to $30 \mathrm{ng}$ of cfDNA in two hours. The ThruPLEX $^{\mathrm{TM}}$ Plasma-seq kit can be used with Illumina platforms for whole genome sequencing or for target enrichment workflows. Finally, the KAPA Hyper Prep Kit from KAPA Biosystems provides a library construction protocol that is compatible with Illumina sequencing and is suitable for FFPE samples and cfDNA with as few as $1 \mathrm{ng}$ of input DNA. This kit can be used for different NGS applications, including whole genome and target enrichment sequencing.

\section{Comparison of NGS platforms}

Several studies have been conducted to compare NGS platforms. First, Quail et al. compared the Ion Torrent $^{\mathrm{TM}}$ PGM, Illumina MiSeq, Illumina HiSeq, Illumina GAIIx and $\mathrm{PacBio}^{\circledR}$ (Pacific Biosciences) platforms using microbial genomes covering different GC contents. Of note, this study shows the error rates between platforms ( $<0.4 \%$ for Illumina, $1.78 \%$ for Ion Torrent ${ }^{\mathrm{TM}}$, and $13 \%$ for Pacific Biosciences) and the poor performance of the Ion Torrent ${ }^{\mathrm{TM}} \mathrm{PGM}$ in sequencing the extremely GC-poor genome of Plasmodium falciparum, resulting in 30\% of the genome being uncovered [76]. Moreover, differences were observed in the rates of correct SNP calls (68-76\% for Illumina, $82 \%$ for Ion Torrent ${ }^{\mathrm{TM}}$, and $71 \%$ for Pacific Biosciences) and in the rates of false SNP calls [76]. Importantly, the Ion Torrent ${ }^{\mathrm{TM}} \mathrm{PGM}$ generated more false positive SNP calls than the Illumina platforms. These results are in concordance with the previously reported higher base call accuracy of Illumina platforms when 
Table 2a: Results from selected mutational analysis studies.

\begin{tabular}{|c|c|c|c|c|c|}
\hline Reference & Cancer Type & Tissue Type & Methods & $\begin{array}{c}\text { Genes/ } \\
\text { Mutations }\end{array}$ & Results \\
\hline [89] & NSCLC & $\begin{array}{l}\text { Plasma } \\
\text { cfDNA and } \\
\text { tumor tissue }\end{array}$ & $\begin{array}{l}\text { Therascreen }{ }^{\circledR} \text { Real-Time } \\
\text { PCR and peptide nucleic } \\
\text { acid (PNA) clamp Real- } \\
\text { Time PCR }\end{array}$ & $\begin{array}{l}\text { EGFR exon } 19 \\
\text { del, L858R }\end{array}$ & $\begin{array}{l}\text { Therascreen }{ }^{\circledR} \text { RT-PCR: } 65.4 \% \text { sensitivity (sens.), } 100 \% \\
\text { specificity (spec.); } 55 \% \text { detection for exon } 19 \text { del. in plasma } \\
\text { cfDNA compared to tissue, } 100 \% \text { detection for L858R in } \\
\text { plasma cfDNA compared to tissue } \\
\text { PNA clamp: } 61.5 \% \text { sens., } 100 \% \text { spec.; } 50 \% \text { detection for } \\
\text { exon } 19 \text { del in plasma cfDNA compared to tissue, } 100 \% \\
\text { detection for L858R in plasma cfDNA compared to tissue }\end{array}$ \\
\hline$[90]$ & NSCLC & $\begin{array}{l}\text { Plasma and } \\
\text { serum cfDNA } \\
\text { and tumor } \\
\text { tissue }\end{array}$ & $\begin{array}{l}\text { PNA clamp Real-Time } \\
\text { PCR (Taqman) }\end{array}$ & $\begin{array}{l}\text { EGFR exon } 19 \\
\text { del, L858R }\end{array}$ & $\begin{array}{l}\text { PNA clamp (Taqman): } 78 \% \text { overall concordance rate } \\
\text { between plasma/serum cfDNA and tissue, } 83.9 \% \text { exon } 19 \text { del } \\
\text { concordance rate, } 70.7 \% \text { L } 858 \text { R concordance rate } \\
\text { Overall survival (OS): Median OS was shorter in patients } \\
\text { with L858R than exon } 19 \text { del in cfDNA (13.7 months, } 95 \% \\
\text { CI } 7.1-17.7 \text {, versus } 30.0 \text { months, } 95 \% \text { CI } 19.3-37.7 \text { ) }\end{array}$ \\
\hline [91] & NSCLC & $\begin{array}{l}\text { Serum cfDNA } \\
\text { and tumor } \\
\text { tissue }\end{array}$ & $\begin{array}{l}\text { Amplification Refractory } \\
\text { Mutation System } \\
\text { (ARMS) and Scorpion } \\
\text { real-time PCR }\end{array}$ & $E G F R$ & $\begin{array}{l}\text { NGS: } 23.7 \% \text { detection rate in cfDNA, } 61.5 \% \text { detection rate } \\
\text { in tumor tissue; } 56.9 \% \text { false negative rate for cfDNA } \\
\text { Progression Free Survival (PFS): For patients positive for } \\
\text { EGFR mutations, those who received gefitinib had longer } \\
\text { PFS than those who received carboplatin-paclitaxel. }\end{array}$ \\
\hline [93] & NSCLC & $\begin{array}{l}\text { Plasma } \\
\text { cfDNA and } \\
\text { tumor tissue }\end{array}$ & ARMS Real-Time PCR & $E G F R$ & $\begin{array}{l}\text { Overall sensitivity in cfDNA: } 17.2 \% \\
\text { Higher sensitivity in later-stage patients: } 1.6 \% \text { in stage IA, } \\
7.9 \% \text { in stage IB, } 11.1 \% \text { in stage IIA, } 20.0 \% \text { in stage IIB, } \\
\text { and } 33.3 \% \text { in stage IIIA } \\
\text { Higher sensitivity with lower levels of tumor differentiation: } \\
0 \%, 15.7 \% \text { and } 36.8 \% \text { in highly, moderately and poorly } \\
\text { differentiated tumors, respectively. } \\
\text { Positive ratios of plasma cfDNA compared to tumor tissue: } \\
\text { Exon } 19 \text { del: } 22.5 \% \text {, L } 858 \text { R: } 7.0 \% \text {, L } 861 Q: 75.0 \% \text {, exon } 20 \\
\text { insertions: } 14.3 \% \text {; T790M, G719X, S7681: } 0 \%\end{array}$ \\
\hline [94] & NSCLC & $\begin{array}{l}\text { Plasma } \\
\text { cfDNA and } \\
\text { tumor tissue }\end{array}$ & $\begin{array}{l}\text { Droplet digital PCR } \\
\text { (ddPCR) and ARMS }\end{array}$ & $\begin{array}{l}\text { EGFR exon } 19 \\
\text { del, L858R }\end{array}$ & $\begin{array}{l}\text { ddPCR of cfDNA compared to ARMS tumor analysis: } \\
\text { Exon } 19 \text { del: } 81.8 \% \text { sens., } 98.4 \% \text { spec., } 94.2 \% \text { concordance } \\
\text { L858R: } 80.0 \% \text { sens., } 95.8 \% \text { spec., } 93.0 \% \text { concordance } \\
\end{array}$ \\
\hline [95] & NSCLC & $\begin{array}{l}\text { Plasma } \\
\text { cfDNA and } \\
\text { tumor tissue }\end{array}$ & ddPCR & $\begin{array}{l}\text { EGFR exon } 19 \\
\text { del, L858R, } \\
\text { T790M }\end{array}$ & $\begin{array}{l}\text { Exon } 19 \text { del: } 76.5 \% \text { sens., } 100 \% \text { spec., } 86.2 \% \text { concordance } \\
\text { with tumor tissue before treatment } \\
\text { L858R: } 70.8 \% \text { sens., } 100 \% \text { spec., } 87.9 \% \text { concordance with } \\
\text { tumor tissue before treatment } \\
\text { Response to TKI: } 40 \text { patients with either L } 858 \text { R or exon } \\
19 \text { del in cfDNA at baseline showed a decrease in mutant } \\
\text { levels after treatment. The T790M mut. was detected in } \\
8 \text { patients } 2-12 \text { months before progression was detected } \\
\text { radiographically and in } 6 \text { patients at progression. }\end{array}$ \\
\hline [96] & NSCLC & $\begin{array}{l}\text { Plasma } \\
\text { cfDNA and } \\
\text { tumor tissue }\end{array}$ & $\begin{array}{l}\text { ARMS and combination } \\
\text { of mutant enriched PCR } \\
\text { (me-PCR) and denaturing } \\
\text { high performance } \\
\text { liquid chromatography } \\
\text { (DHPLC) }\end{array}$ & $\begin{array}{l}\text { EGFR exon } 19 \\
\text { del, L858R }\end{array}$ & $\begin{array}{l}\text { Me-PCR and DHPLC: } 77.3 \% \text { sens., } 89.6 \% \text { spec., } 85.1 \% \\
\text { concordance between cfDNA (me-PCR and DHPLC) and } \\
\text { tissue (ARMS) } \\
\text { Response to TKI: } \\
\text { In tumor tissue: Objective response rate (ORR) of } 69.4 \% \text { for } \\
\text { patients with EGFR mutations; ORR of } 13.0 \% \text { for patients } \\
\text { without EGFR mutations } \\
\text { In plasma cfDNA: ORR of } 64.5 \% \text { for patients with } E G F R \\
\text { mutations; ORR of } 28.6 \% \text { for patients without } E G F R \text { mut. }\end{array}$ \\
\hline [97] & NSCLC & $\begin{array}{l}\text { Plasma } \\
\text { cfDNA and } \\
\text { tumor tissue }\end{array}$ & ddPCR and NGS & $E G F R$ & $\begin{array}{l}\text { ddPCR: } 74 \% \text { concordance rate between cfDNA and tissue } \\
\text { Survival: Longer PFS and OS for patients with EGFR } \\
\text { mutations in cfDNA and tumor samples versus EGFR } \\
\text { mutations only in tumor (Median: PFS: } 12.6 \text { months versus } \\
6.7 \text { months; OS: } 35.6 \text { months versus } 23.8 \text { months) } \\
\text { ddPCR and NGS: Limit of quantification: } 0.04 \% \text { for ddPCR, } \\
5 \% \text { for NGS; NGS had } 89 \% \text { sens. and } 100 \% \text { spec. }\end{array}$ \\
\hline [98] & NSCLC & $\begin{array}{l}\text { Plasma } \\
\text { cfDNA and } \\
\text { tumor tissue }\end{array}$ & Digital PCR & $E G F R$ T790M & $\begin{array}{l}\text { Activating Tumor Mutations: } 88.2 \% \text { of tumor samples had } \\
\text { EGFR mutations; } 58.8 \% \text { of plasma cfDNA samples had } \\
\text { EGFR mutations. } \\
\text { Resistance Mutations: T790M mutation in plasma cfDNA } \\
\text { detected in patients after receiving EGFR-TKIs; } 81.8 \% \\
\text { sensitivity, } 85.7 \% \text { specificity, } 83.3 \% \text { concordance between } \\
\text { plasma cfDNA and tumor tissue }\end{array}$ \\
\hline
\end{tabular}


Table 2b: Results from selected mutational analysis studies.

\begin{tabular}{|c|c|c|c|c|c|}
\hline Reference & Cancer Type & Tissue Type & Methods & $\begin{array}{l}\text { Genes/ } \\
\text { Mutations }\end{array}$ & Results \\
\hline [99] & NSCLC & $\begin{array}{l}\text { Plasma } \\
\text { cfDNA and } \\
\text { tumor tissue }\end{array}$ & $\begin{array}{l}\text { Plasma ddPCR and } \\
\text { tumor genotyping }\end{array}$ & $\begin{array}{l}\text { EGFR exon } 19 \\
\text { del, L858R, } \\
\text { T790M } \\
\text { and KRAS } \\
\text { mutations }\end{array}$ & $\begin{array}{l}\text { ddPCR of cfDNA compared to tumor genotyping: } \\
\text { EGFR Exon } 19 \text { deletion: } 100 \% \text { positive predictive value } \\
\text { (PPV) and } 82 \% \text { sensitivity } \\
\text { EGFR L858R: } 100 \% \text { PPV and } 74 \% \text { sensitivity } \\
\text { EGFR T790M: } 79 \% \text { PPV and } 77 \% \text { sensitivity } \\
\text { KRAS G12X: } 100 \% \text { PPV and } 64 \% \text { sensitivity }\end{array}$ \\
\hline [100] & NSCLC & $\begin{array}{l}\text { Plasma } \\
\text { cfDNA and } \\
\text { tumor tissue }\end{array}$ & $\begin{array}{l}\text { Cobas }{ }^{\circledR} \text { EGFR } \\
\text { Mutation Test, } \\
\text { Therascreen }{ }^{\circledR} \text { EGFR } \\
\text { Mutation Test, ddPCR } \\
\text { and BEAMing dPCR }\end{array}$ & $\begin{array}{l}\text { EGFR exon } 19 \\
\text { del, L858R and } \\
\text { T790M }\end{array}$ & $\begin{array}{l}\text { In a first set of } 38 \text { plasma samples: } \\
\text { Cobas } ₫ \text { Test: } 86 \% \text { and } 90 \% \text { sens., } 100 \% \text { spec., } 89 \% \text { and } \\
97 \% \text { concordance with tumor tissue for } E G F R \text { exon } 19 \text { del } \\
\text { and L858R, resp. } \\
\text { Therascreen } ® \text { Test: } 82 \% \text { and } 78 \% \text { sens., } 100 \% \text { spec., } 87 \% \\
\text { and } 95 \% \text { concordance with tumor tissue for } E G F R \text { exon } 19 \\
\text { del and } L 858 \mathrm{R} \text {, resp. } \\
\text { ddPCR: } 90 \% \text { sens., } 100 \% \text { spec., } 97 \% \text { concordance with } \\
\text { tumor tissue for } E G F R \text { L } 858 \mathrm{R} \\
\text { BEAMing dPCR: } 93 \% \text { and } 100 \% \text { sens., } 100 \% \text { and } 93 \% \\
\text { spec., } 95 \% \text { concordance with tumor tissue for } E G F R \text { exon } 19 \\
\text { del and L858R, resp. } \\
\text { In a second set of } 72 \text { plasma samples: } \\
\text { Cobas } 囚 \text { Test: } 73 \% \text { sens., } 67 \% \text { spec. for } E G F R \text { T790M } \\
\text { BEAMing dPCR: } 81 \% \text { sens., } 58 \% \text { spec. for } E G F R \text { T790M }\end{array}$ \\
\hline [101] & $\begin{array}{l}\text { NSCLC with } \\
\text { EGFR exon } 19 \\
\text { del or L858R } \\
\text { and acquired } \\
\text { EGFR-TKI } \\
\text { resistance, selected } \\
\text { for AZD9291 } \\
\text { treatment }\end{array}$ & $\begin{array}{l}\text { Plasma } \\
\text { cfDNA }\end{array}$ & BEAMing dPCR & EGFR T790M & $\begin{array}{l}\text { Outcomes on AZD9291: } \\
\text { If cfDNA EGFR T790M-positive, ORR of } 63 \% \text { and median } \\
\text { PFS of } 9.7 \text { months } \\
\text { If tumor EGFR T790M-positive, ORR of } 62 \% \text { and median } \\
\text { PFS of } 9.7 \text { months } \\
\text { Conclusions: If cfDNA is T790M-positive, no need for tumor } \\
\text { genotyping. However, if cfDNA is T790M-negative, tumor } \\
\text { genotyping is warranted }\end{array}$ \\
\hline [102] & $\begin{array}{l}\text { NSCLC with } \\
\text { acquired resistance } \\
\text { to AZD9291 } \\
\text { treatment }\end{array}$ & $\begin{array}{l}\text { Plasma } \\
\text { cfDNA }\end{array}$ & NGS and ddPCR & $\begin{array}{l}\text { EGFR exon } 19 \\
\text { del, L858R, } \\
\text { T790M and } \\
\text { C797S }\end{array}$ & $\begin{array}{l}\text { Upon AZD9291 treatment, different resistance phenotypes can } \\
\text { emerge from EGFR T790M-positive patients : } \\
\text { Acquisition of EGFR C797S, maintenance of T790M } \\
\text { positivity without C797S or loss of } E G F R \text { T790M. } \\
\text { Conclusions: Several mechanisms result in the emergence of } \\
\text { resistance to AZD9291. Therapies that overcome resistance } \\
\text { due to } E G F R \text { C797S mutation are needed. }\end{array}$ \\
\hline [103] & NSCLC & Tumor tissue & $\begin{array}{l}\text { Targeted NGS and } \\
\text { Real-Time PCR }\end{array}$ & $\begin{array}{l}E G F R \text { T790M } \\
\text { and other } \\
\text { EGFR and } \\
\text { non-EGFR } \\
\text { mutations } \\
\end{array}$ & $\begin{array}{l}\text { NGS: T790M detected in } 60.0 \% \text { of patients (all patients } \\
\text { previously treated with EGFR-TKIs); Other mutations } \\
\text { detected: TP53 P72R ( } 86.7 \%), K D R \text { Q472H (33.3\%), and } \\
\text { KIT M541L (13.3\%); NGS is able to detect T790M mutation } \\
\text { better than real-time PCR }\end{array}$ \\
\hline [104] & NSCLC & Tumor tissue & NGS deep sequencing & $E G F R$ & $\begin{array}{l}\text { NGS: } 24.6 \% \text { of samples had compound mutations; } 66.7 \% \text { of } \\
\text { compound mutations had an atypical mutation with } E G F R- \\
\text { TKI sensitizing mutation } \\
\text { Survival: Shorter OS for patients with compound mutations } \\
\text { (72.8 months) versus patients without compound mutations } \\
(83.7 \text { months) } \\
\text { Co-occurring mutations: Patients with compound mutations } \\
\text { are more likely to have co-occurring mutations in other } \\
\text { genes than patients with simple mutations }\end{array}$ \\
\hline [105] & NSCLC & $\begin{array}{l}\text { Plasma } \\
\text { cfDNA, } \\
\text { malignant } \\
\text { pleural } \\
\text { effusion } \\
\text { (MPE), and } \\
\text { tumor tissue }\end{array}$ & $\begin{array}{l}\text { ARMS for all samples, } \\
\text { Sanger sequencing and } \\
\text { immunohistochemistry } \\
\text { (IHC) for MPE cell } \\
\text { block and tumor tissue } \\
\text { samples }\end{array}$ & $E G F R$ & $\begin{array}{l}\text { ARMS: } \\
\text { In MPE cell block samples compared to tissue: } 81.8 \% \text { sens., } \\
80.0 \% \text { spec., } 81 \% \text { concordance } \\
\text { In MPE supernatant compared to tissue: } 63.6 \% \text { sens., } 100 \% \\
\text { spec., } 81 \% \text { concordance } \\
\text { In plasma cfDNA compared to tissue: } 67.5 \% \text { sens., } 100 \% \\
\text { spec., } 84.9 \% \text { concordance } \\
\text { In MPE supernatant compared to MPE cell block: } 69.2 \% \\
\text { sens., } 100 \% \text { spec., } 85.2 \% \text { concordance } \\
\text { Sanger sequencing compared to ARMS: } \\
\text { In tumor: } 81.8 \% \text { sens., } 100 \% \text { spec., } 91.3 \% \text { concordance } \\
\text { In MPE cell blocks: } 40 \% \text { sens., } 100 \% \text { spec., } 72.7 \% \\
\text { concordance } \\
\text { IHC compared to ARMS: } \\
\text { In tumor: } 54.8 \% \text { sens., } 97.1 \% \text { spec., } 77.3 \% \text { concordance } \\
\text { In MPE cell blocks: } 50 \% \text { sens., } 100 \% \text { spec., } 76.9 \% \\
\text { concordance }\end{array}$ \\
\hline
\end{tabular}


Table 2c: Results from selected mutational analysis studies.

\begin{tabular}{|c|c|c|c|c|c|}
\hline Reference & Cancer Type & Tissue Type & Methods & $\begin{array}{l}\text { Genes/ } \\
\text { Mutations }\end{array}$ & Results \\
\hline$[106]$ & NSCLC & $\begin{array}{l}\text { Plasma } \\
\text { cfDNA and } \\
\text { tumor tissue }\end{array}$ & NGS deep sequencing & $\begin{array}{l}\text { EGFR exon } 19 \\
\text { del, T790M, } \\
\text { L858R }\end{array}$ & $\begin{array}{l}\text { NGS of plasma cfDNA compared to tissue samples: } \\
\text { For exon } 19 \text { deletions: } 50.9 \% \text { sens., } 98.0 \% \text { spec. } \\
\text { For L858R: } 51.9 \% \text { sens., } 94.1 \% \text { spec. } \\
\text { For T790M in patients after EGFR-TKI: } 94.2 \% \text { spec. }\end{array}$ \\
\hline$[107]$ & NSCLC & $\begin{array}{l}\text { Plasma } \\
\text { cfDNA, } \\
\text { tumor tissue, } \\
\text { whole blood } \\
\text { circulating } \\
\text { tumor cells } \\
\text { (CTC) }\end{array}$ & $\begin{array}{l}\text { Targeted NGS with } \\
\text { PCR amplification and } \\
\text { Cobas } \AA \text { EGFR PCR }\end{array}$ & EGFR T790M & 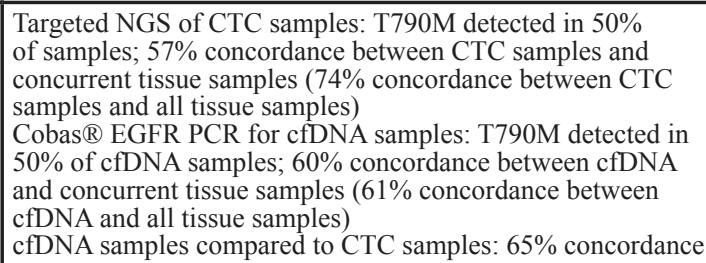 \\
\hline$[110]$ & NSCLC & $\begin{array}{l}\text { Plasma } \\
\text { cfDNA and } \\
\text { tumor tissue }\end{array}$ & $\begin{array}{l}\text { Cobas }{ }^{\circledR} \text { EGFR PCR } \\
\text { and ultra deep NGS }\end{array}$ & $\begin{array}{l}E G F R \text { exon } 19 \\
\text { del, T790M, } \\
\text { L858R }\end{array}$ & $\begin{array}{l}\text { Cobas }{ }^{\circledR} \text { PCR for cfDNA: } 72 \% \text { sens., } 100 \% \text { spec.; } 71 \% \\
\text { baseline concordance rate between plasma cfDNA and tissue, } \\
73 \% \text { progression concordance rate between plasma cfDNA } \\
\text { and tissue } \\
\text { Ultra Deep NGS for cfDNA: } 74 \% \text { sens., } 100 \% \text { spec.; } 74 \% \\
\text { baseline concordance rate between plasma cfDNA and tissue, } \\
73 \% \text { progression concordance rate between plasma cfDNA } \\
\text { and tissue }\end{array}$ \\
\hline$[121]$ & $\begin{array}{l}\text { Several tumor } \\
\text { types, including } \\
\text { NSCLC }\end{array}$ & Tumor tissue & $\begin{array}{l}\text { NGS, IHC, and } \\
\text { qualitative Real-Time } \\
\text { PCR (qRT-PCR) }\end{array}$ & $M E T$ & $\begin{array}{l}\text { NGS: } M E T \text { exon } 14 \text { mutations detected in } 28 / 933 \text { NSCLC } \\
\text { patients }(3.0 \%) ; 61 \% \text { deletions, } 39 \% \text { point mutations; } 29 \% \\
\text { of patients also had } E G F R \text { copy gain; } 71 \% \text { of patients had at } \\
\text { least } 1 \text { mutation in TP53 or } M D M 2 \\
\text { IHC: c-MET expressed more in stage IV samples with } M E T \\
\text { exon } 14 \text { mutations than stage I-III samples with } M E T \text { exon } 14 \\
\text { mutations } \\
\text { qRT-PCR: } M E T \text { exon } 14 \text { skipping occurred in } 96 \% \text { of samples } \\
\text { tested }\end{array}$ \\
\hline$[122,123]$ & $\begin{array}{l}\text { Several tumor } \\
\text { types, including } \\
\text { NSCLC }\end{array}$ & Tumor tissue & Targeted NGS & $M E T$ & $\begin{array}{l}\text { NGS: } M E T \text { mutations detected in } 221 / 38,028 \text { specimens, } \\
3 \% \text { of which (131) were lung adenocarcinomas; } M D M 2 \\
\text { and } C D K 4 \text { amplification often occurred with } M E T \text { exon } 14 \\
\text { splicing mutations but not with } M E T \text { amplification; Patients } \\
\text { with } M E T \text { exon } 14 \text { alterations, including } \\
\text { c. } 2888-5 \text { 2944del62, c. } 3028 \mathrm{G}>\mathrm{C} \text {, and c. } 3028+1 \mathrm{G}>\mathrm{T} \text {, showed } \\
\text { partial responses to MET inhibitors }\end{array}$ \\
\hline $\begin{array}{l}{[124] \text { case }} \\
\text { report }\end{array}$ & $\begin{array}{l}\text { NSCLC- } \\
\text { Sarcomatoid }\end{array}$ & $\begin{array}{l}\text { Metastasis of } \\
\text { primary lung } \\
\text { tumor }\end{array}$ & NGS & $M E T$ & $\begin{array}{l}\text { Mutations detected: c. } 2888-5 \text { _2890TTAAGATC }>\text { A and } \\
\text { c. } 3028+2 \mathrm{~T}>\mathrm{G} \text { (both thought to contribute to exon } 14 \\
\text { skipping), p.H1094Y (c.3280C }>\text { T) } \\
\text { Crizotinib response: partial response, decrease in lung mass }\end{array}$ \\
\hline $\begin{array}{l}{[125] \text { case }} \\
\text { report }\end{array}$ & $\begin{array}{l}\text { NSCLC- } \\
\text { Adenocarcinoma }\end{array}$ & $\begin{array}{l}\text { Adrenal } \\
\text { lesion- } \\
\text { metastasis of } \\
\text { primary lung } \\
\text { tumor } \\
\end{array}$ & NGS & $M E T$ & $\begin{array}{l}\text { Mutation detected: Intronic deletion } \\
\text { c. } 2887-18 \text { 2887-7del12 } \\
\text { Crizotinib response: lung mass improvement and decrease in } \\
\text { size of adrenal lesion after } 5 \text { weeks }\end{array}$ \\
\hline $\begin{array}{l}{[126] \text { case }} \\
\text { report }\end{array}$ & $\begin{array}{l}\text { NSCLC- } \\
\text { Adenocarcinoma }\end{array}$ & $\begin{array}{l}\text { Metastasis of } \\
\text { primary lung } \\
\text { tumor }\end{array}$ & NGS & $M E T$ & $\begin{array}{l}\text { Mutations Detected: } \\
\text { MET c.2888-19>2888-2delCTTTCTCTCTGTTTTAA, } \\
\text { c.3028G }>\text { C, c.3028+1G }>\text { A, } \\
\text { c.3024_3028delAGAAGGTATATT, p.V1001 } \\
\text { F1007del (c.3001_3021delGTAGACTACCGA } \\
\text { GCTACTTTT), c. } 3028+1 G>\text { T, c.3028G }>\text { T, and } \\
\text { c.3017 3028delCTTTTCCAGAAGGT } \\
\text { MET TKI response: } 3 / 4 \text { patients who received TKIs exhibited } \\
\text { complete or partial responses }\end{array}$ \\
\hline
\end{tabular}

compared to the Ion Torrent ${ }^{\mathrm{TM}}$ PGM (Phred quality score (Q) > 30 for Illumina and Q20 for the Ion Torrent ${ }^{\mathrm{TM}}$ PGM, corresponding to an incorrect base call probability of $1 / 1000$ and $1 / 100$, respectively) $[76,77]$. When compared to the Illumina and Ion Torrent ${ }^{\mathrm{TM}}$ platforms, the PacBio ${ }^{\circledR}$ platform has high error rates $(<\mathrm{Q} 10)$, generates reads at lower throughput, and is more expensive [76, 77]. Moreover, when comparing the DNA requirements of each platform for standard library preparation, Illumina and Ion Torrent ${ }^{\mathrm{TM}}$ surpass $\mathrm{PacBio}^{\circledR}$ given that far less
DNA is needed with the first two platforms [76]. These features may hamper the use of $\mathrm{PacBio}^{\circledR}$ for applications where only limiting amounts of DNA are available such as cfDNA sequencing. By virtue of its very long reads ( $1,500 \mathrm{bp}$ for the first generation of $\mathrm{PacBio}^{\circledR} \mathrm{RS}$ system and $>10 \mathrm{~kb}$ for the PacBio ${ }^{\circledR}$ RS II) PacBio ${ }^{\circledR}$ sequencing is not suited for the fragmented cfDNA analysis but rather for de novo genome assembly [77]. Despite differences in data generated, the Ion Torrent ${ }^{\mathrm{TM}}$ PGM and Illumina platforms were comparable in terms of reliability of results when 
sequencing GC-rich or GC-balanced genomes such as the human genome [76].

Next, in a study that compared the Roche 454 and Ion Torrent ${ }^{\mathrm{TM}}$ PGM platforms as well as the mutationspecific platforms, $\operatorname{Cobas}^{\circledR}$ z 480 analyzer (Roche) and Rotor-Gene Q (Qiagen), Hinrichs et al. looked for $K R A S$ and EGFR mutations in 25 FFPE samples from lung cancer patients. In 14 out of 25 samples, KRAS mutations that had been previously detected by Sanger sequencing combined with high-resolution melting (HRM) were detected by the Cobas ${ }^{\circledR}$, Rotor-Gene, and Ion Torrent $^{\mathrm{TM}}$ platforms [78]. In 10 out of these 14 samples, the Roche 454 could also detect the relevant mutations. The four other "mutated" samples and one "unmutated" sample could not be analyzed with Roche 454 because of technical sequencing issues (generation of unspecific PCR products), while all of the clinically relevant $E G F R$ mutations that had been detected with HRM and Sanger sequencing were detected with all four platforms [78]. Notably, the Roche 454 generated 53,000 high quality reads (ca. 360 reads/amplicon), while the Ion Torrent ${ }^{\mathrm{TM}}$ PGM generated 4,000,000 high quality reads (ca. 1,500 reads/amplicon) [78]. This study demonstrates that, compared to Roche 454, NGS sequencing on the Ion Torrent $^{\mathrm{TM}}$ PGM platform is more informative and faster.

Finally, Li et al. compared mutations found in inherited cardiac disease patients on the Illumina MiSeq and the Ion Torrent ${ }^{\mathrm{TM}}$ PGM platforms. In terms of target enrichment, $98.8 \%$ of the target region was covered at least once with the Illumina MiSeq platform, and 98.0\% of the target region was covered with the Ion Torrent ${ }^{\mathrm{TM}}$ PGM platform [79]. Moreover, both platforms had greater than 200 reads for every protein-coding region of each gene [79]. In addition, the Illumina MiSeq and Ion Torrent ${ }^{\mathrm{TM}}$ PGM sequenced $97.9 \%$ and $96.8 \%$ of the target respectively, with a variant calling sensitivity of $100 \%$ for the MiSeq and $99.1 \%$ for the PGM [79]. The Illumina MiSeq required one sequencing run that cost $\$ 959$ (\$64 per specimen), while the Ion Torrent ${ }^{\mathrm{TM}}$ PGM required three sequencing runs that cost $\$ 686$ each $(\$ 137$ per specimen) [79]. Furthermore, despite the cheaper cost of the Ion Torrent ${ }^{\mathrm{TM}}$ PGM per run and its faster run time (3x3 hours) when compared to Illumina MiSeq (27 hours), the increased hands-on time and technical complexity of the Ion Torrent ${ }^{\mathrm{TM}}$ PGM platform resulted in a higher cost per sample than the Illumina MiSeq [79]. Given that the results obtained by each platform were comparable, the differences between the two platforms are the cost and the total amount of time required per run.

When choosing a platform to use in the clinic, several factors are important to consider, including the price of the system, the price per specimen, the sensitivity of the system, the run time required, and the relative ease of data analysis and interpretation. In terms of cost, in 2013, the Ion Torrent ${ }^{\mathrm{TM}}$ PGM cost $\$ 75 \mathrm{~K}$, the Illumina MiSeq system cost \$125 K, and the Illumina HiSeq 2000 system cost $\$ 654 \mathrm{~K}[76,79]$. However, the Illumina platforms cost less per million bases $(\$ 0.03$ to $\$ 0.04$ with the Illumina HiSeq 2500 versus $\$ 0.1$ with the Ion Torrent $^{\mathrm{TM}} \mathrm{PGM}$ ) [77] and per specimen ( $\$ 64$ per specimen for the Illumina MiSeq versus $\$ 137$ per specimen for the Ion Torrent $\left.{ }^{\mathrm{TM}} \mathrm{PGM}\right)[76,79]$. Given the studies presented above, despite some differences, the sensitivity of these systems and the amount of DNA required are relatively comparable (10 ng for low input kits for potential use with cfDNA, 50-250 ng DNA for other kits), so decisions need to be made based upon cost and time required to run. However, if cfDNA analysis is to be performed with NGS, one additional point to consider when deciding whether to purchase one platform versus another platform is the compatibility of the library preparation kit with the platform. Next, in terms of the run time, in general, the Illumina platforms take longer to run than the Ion Torrent $^{\mathrm{TM}}$ platforms (27 hours for the MiSeq and 11 days for the HiSeq 2000 versus two to four hours for the Ion Torrent $^{\mathrm{TM}}$ PGM) $[76,79]$. Finally, in terms of data analysis, Ion Torrent ${ }^{\mathrm{TM}}$ Suite software is used for analysing data generated on Ion systems. The Ion Reporter software

\section{Chromosome 7: MET}

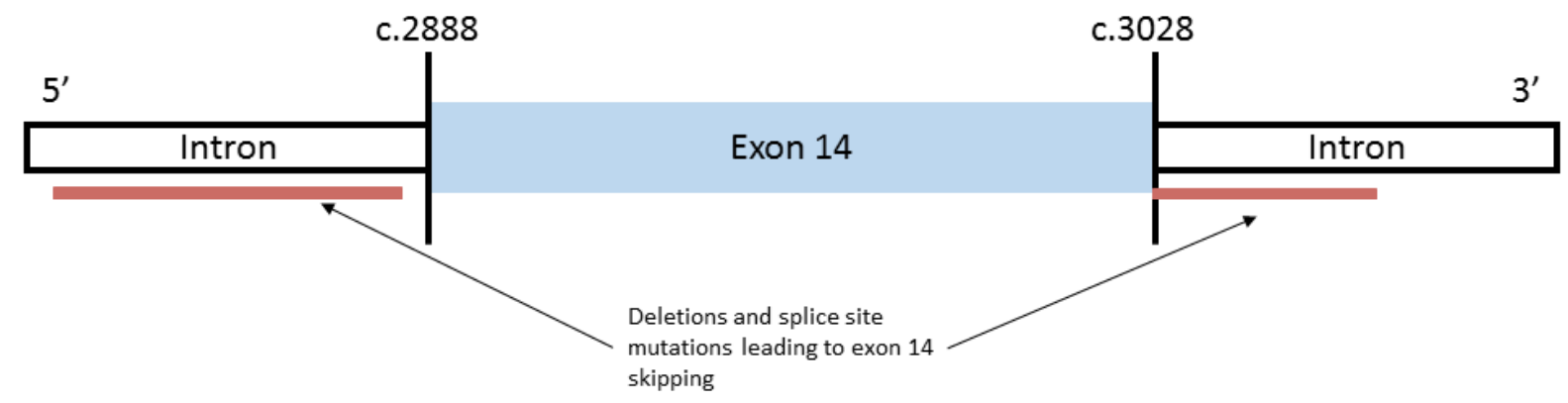

Figure 3: Schematic representation of $M E T$ mutations that lead to exon 14 skipping. Mutations include but are not limited to c.2888-5_2944del62, c.3028G > C, c.3028+1G > T, p.H1094Y (c.3280C > T), c.2888-5_2890TTAAGATC > A, c.2888-19> 2888-2delCTTTCTCTCTGTTTTAA, c.3028+1G > A, c.3024_3028delAGAAGGTATATT, p.V1001_F1007del (c.3001_3021delGTAGA CTACCGAGCTACTTTT), and c.3017_3028delCTTTTCCAGAAGGT. 
facilitates data analysis, annotation, and visualization. For Illumina platforms, variant calling is performed with the MiSeq Reporter software that uses an alignment algorithm called the Burrows-Wheeler Aligner (BWA).

\section{NGS compared to other detection methods}

As NGS becomes more prevalent in molecular diagnostics, comparing results obtained by NGS to results obtained by other techniques is vital for validating the use of NGS in a clinical setting. Thus, when targeted NGS results were compared to results obtained by real-time PCR for tumor samples from patients with NSCLC, the two methods had high concordance rates for the three genes tested: $96.3 \%$ for $E G F R, 98.7 \%$ for $K R A S$, and $100 \%$ for $B R A F$ [80]. In addition, targeted NGS identified eight $E G F R$ indels and SNVs that were not detected by the real-time PCR method used [80]. Moreover, when results obtained from targeted NGS were compared to results obtained by immunohistochemistry (IHC) for tumor samples from NSCLC patients with EGFR mutations, the fair sensitivity of the mutant-specific antibodies (58.4\%) did not favor the replacement of DNA sequencing by IHC for the detection of EGFR mutations. However, it is noteworthy that the specificity of IHC using mutated EGFR antibodies is excellent (98.0\%) [81]. Finally, in a study to compare hybrid capture-based NGS with mass spectrometry genotyping and fluorescence in situ hybridization (FISH), NGS revealed actionable genomic alterations in $65 \%$ of solid lung tumors that were classified as negative by the other non-NGS methods [82]. Based on these studies, NGS is a superior method for detecting targetable mutations in lung tumors and would provide more sensitivity in lung cancer diagnosis.

\section{GENETIC ANALYSIS}

In the following section, selected studies that sought to characterize $E G F R$ and $M E T$, two frequently mutated genes occurring in lung cancer, using NGS or PCR-based techniques with cfDNA and solid tumor samples are presented, and results are summarized in Table 2a, 2b, 2c.

\section{EGFR mutations}

The epidermal growth factor receptor (EGFR) is a receptor tyrosine kinase responsible for activating downstream proteins and signal cascades, including the RAS/RAF/MAPK and PI3K/AKT pathways [83]. Mutations in EGFR result in abnormal receptor activity leading to increased signaling. These mutations are observed in $10 \%$ to $30 \%$ of NSCLC cases with higher frequencies in the East Asian population than the Caucasian population $[83,84]$. In patients with $E G F R$ mutations, EGFR tyrosine kinase inhibitors (EGFR
TKIs), including erlotinib and gefitinib, are generally given as first-line treatments [85-87]. However, some patients develop resistance to TKIs, often related to a mutation in exon 20 of EGFR resulting in a substitution of methionine to threonine at amino acid position 790 [88]. In personalized medicine, detecting EGFR-activating mutations and monitoring for resistance mutations enable physicians to prescribe treatments and modify them as necessary. In order to do this, non-invasive and efficient methods to detect EGFR mutations have been developed using cfDNA as a liquid biopsy sample and NGS as technique for mutational analysis.

First, cfDNA samples can be analyzed to detect and monitor EGFR-activating mutations in patients with lung cancer. Pasquale et al. used real-time PCR assays to detect EGFR L858R mutations and exon 19 deletions in plasma cfDNA from NSCLC patients. They demonstrated that the Plasma-Therascreen ${ }^{\circledR}$ method (ARMS (Amplification Refractory Mutation System) allele-specific real-time PCR using the fluorescent Scorpions probes) and the Peptide Nucleic Acid (PNA)-clamp approach (inhibition of the amplification of the wild-type allele) have similar sensitivities (65.4\% and $61.5 \%$, respectively), specificities (100\% for both methods), and concordance rates $(90.6 \%$ and $89.6 \%$, respectively) for the detection of the same EGFR mutation present in cfDNA and the corresponding primary tumor [89]. In a different study, Karachaliou et al. analyzed EGFR mutations in cfDNA from blood samples collected from 97 untreated patients enrolled in the European Tarceva versus Chemotherapy (EURTAC) trial $[86,90]$. The authors demonstrated that in patients with the L858R mutation in tissue, who received erlotinib or standard chemotherapy, the detection of L858R in cfDNA is a negative prognostic factor for overall survival (OS), and patients with the L858R mutation in cfDNA had shorter OS than patients with exon 19 deletions [90]. $E G F R$ mutation detection in cfDNA was successfully achieved using a PNA-mediated 5' nuclease real-time PCR assay with $78 \%$ sensitivity and $100 \%$ specificity [90]. These findings demonstrate the efficacy of this assay in the detection of EGFR mutations in cfDNA and shed light on the need for specific combination therapies for patients bearing the L858R mutation in their blood.

Similarly, using Therascreen ${ }^{\circledR}$ EGFR Mutation Test, Goto et al. analyzed EGFR mutations in 91 tumor samples and 194 cfDNA samples isolated from patients enrolled in the Iressa Pan-Asia (IPASS) study comparing the efficacy of gefitinib and carboplatin/paclitaxel in patients with lung adenocarcinoma [91, 92]. Among the 86 patients who had mutational data for both tissue and cfDNA, the positive predictive value of the cfDNA EGFR mutation test was $100 \%$ [91]. However, there was a high false negative rate $(56.9 \%)$ and a concordance rate of only $66.3 \%$, reflecting either a poor sensitivity of the assay or the absence of cfDNA in some plasma samples [91]. Interestingly, the presence of the mutation in cfDNA or in 
the tissue permitted the same interpretation of treatment effect (higher progression-free survival (PFS) and higher objective response rate (ORR) with gefitinib versus chemotherapy). When compared to the Pasquale el al. study that used the same ARMS-Scorpions PCR approach [89], the sensitivity of the EGFR mutation detection test in cfDNA in the Goto et al. study was considerably lower (43\%) [91]. The different sample types in each study (plasma or serum) and the modifications made in the assay protocol in Goto's study may explain, at least in part, these discrepancies.

In another study, in which ARMS-Scorpions PCR was also used, a very low concordance rate was observed between EGFR mutations found in tumor samples and in plasma cfDNA $(17.2 \%)$; however, this concordance rate increased to $33.3 \%$ in later-stage patients and increased to $36.8 \%$ in patients with poorly differentiated tumors [93]. The differences between these results are likely due not only to technical variations but also to differences in staging. Guo et al. [93] used samples from patients across all stages, while Pasquale et al. [89] and Karachaliou et al. [90] used samples from advanced NSCLC patients. Taken together, these studies indicate that cfDNA could be used to detect EGFR mutations in patients with latestage lung cancer using PCR-based assays. Additionally, using a droplet digital PCR (ddPCR) technique, Zhu et al. demonstrated the high sensitivity of this method in detecting EGFR-activating mutations in cfDNA from patients with late-stage NSCLC [94].

Next, cfDNA samples can be analyzed for mutations in order to predict tumor response to treatment and to determine if resistance mutations have appeared. For example, using ddPCR, Lee et al. compared tumor tissues with known EGFR mutations to plasma cfDNA samples from the same patients and followed the mutational status over time. At baseline, the concordance rate between tissue and plasma cfDNA samples was $87.9 \%$ for the L858R mutation and $86.2 \%$ for exon 19 deletions [95]. Moreover, 40 out of 40 patients who harbored these mutations at baseline showed a decrease in mutant cfDNA after TKI treatment; however, a T790M mutation was detected in 14 patients who progressed after TKI treatment [95]. In a different study, EGFR mutations were detected in $36.4 \%$ of tumor tissue samples and $34.7 \%$ of plasma cfDNA samples [96]. Furthermore, of the 59 patients who received EGFR-TKIs, patients with known $E G F R$ mutations in tissue and plasma cfDNA had higher ORR than patients who were wild-type for EGFR [96]. These findings are consistent with data from other studies using ddPCR [97, 98]. Finally, Sacher et al. demonstrated that plasma ddPCR is a rapid method to detect EGFR exon 19 deletion, L858R, and T790M mutations with high sensitivity and specificity [99].

Importantly, in order to select the most appropriate platform for EGFR mutation detection, in particular T790M, as part of the development process of the irreversible T790M-potent EGFR-TKI AZD9291, Thress et al. performed a cross-platform comparison using plasma samples from advanced-stage NSCLC patients enrolled in the multicenter AURA study. The authors demonstrated the high and comparable sensitivity and specificity of digital (BioRad ddPCR ${ }^{\mathrm{TM}}$ and beads, emulsion, amplification, and magnetics (BEAMing) dPCR) and non-digital (Cobas ${ }^{\circledR}$ EGFR Mutation Test and Therascreen ${ }^{\circledR}$ EGFR Mutation Test) platforms for the detection of EGFR-sensitizing mutations in cfDNA. When comparing the Cobas ${ }^{\circledR}$ EGFR Mutation Test and BEAMing dPCR for EGFR T790M detection in cfDNA, the authors observed a high sensitivity with both tests (73\% and $81 \%$, respectively). These results support the use of both platforms for EGFR T790M detection in cfDNA [100]. Interestingly, Oxnard et al. demonstrated that cfDNA T790M analysis is a viable alternative to tumor T790M genotyping when plasma results are $7790 \mathrm{M}$-positive since similar outcomes with AZD9291 were reported in patients with T790M-positive plasma or tissue [101]. Although EGFR T790M-positive NSCLC tumors are sensitive to the third generation TKIs such as AZD9291, emergence of resistance to these drugs can still occur. One of the resistance mechanisms is the development of the EGFR C797S mutation which blocks drug binding on EGFR. Thress et al. successfully used NGS and ddPCR to detect the EGFR C797S mutation in plasma cfDNA from advanced EGFR-mutant NSCLC patients with acquired resistance to AZD9291 [102]. Based on these studies, cfDNA can be used to predict a patient's response to TKIs through the analysis of EGFR mutations over time.

Moreover, in tumor tissue, targeted NGS has been used to detect the T790M mutation in patients who had $E G F R$-activating mutations and were treated with EGFRTKIs. In addition to EGFR T790M, NGS revealed several other acquired resistance mutations, including mutations in TP53, KDR, and KIT [103], and compound EGFR mutations (i.e. more than one mutation in the EGFR tyrosine kinase domain) [104]. Interestingly, patients with compound EGFR mutations showed significantly lower OS than patients without such mutations (72.8 months versus 83.7 months) [104]. Additionally, to determine if $E G F R$ mutations could be found in other sample types, Liu et al. compared mutations found in tumor tissue, plasma cfDNA, and DNA in pleural effusion samples from patients with advanced NSCLC using three different techniques: ARMS PCR, Sanger sequencing, and IHC. Results from this study indicate that pleural effusion samples and plasma cfDNA can be used to determine EGFR mutational status and that of these three techniques, ARMS PCR is the most suitable [105]. Moreover, Uchida et al. demonstrated that deep sequencing of plasma cfDNA is highly specific for the detection of EGFR mutations, including T790M [106].

Given that the detection rate of EGFR mutations can differ significantly between tumor and cfDNA 
samples, there is a need to address what biopsy sample or combinations of samples provide the most reliable information. To answer this question, in the frame of a multi-institutional Stand-Up-To-Cancer collaboration, Sundaresan et al. analyzed the EGFR T790M mutation in plasma cfDNA samples, circulating tumor cell (CTC) samples from whole blood, and tissue samples from TKItreated patients with advanced NSCLC who were known to harbor EGFR-activating mutations. [107]. Notably, the authors found that although concordance rates did not exceed $65 \%$, each biopsy type provided complementary information to the others, indicating that in clinical practice, more than one biopsy or sample type could be required for complete analysis [107]. This conclusion is in agreement with the findings of Oxnard et al. who showed that when EGFR T790M mutation is not detected in cfDNA, a tumor biopsy is still needed to determine T790M mutation status [101].

In practice, there is no consensus if one test or another is better suited for the detection of $E G F R$ mutations in the clinic, particularly when using cfDNA. However, based on the studies mentioned above and on important, multicenter trials in lung cancer such as EURTAC, IPASS and LUX-Lung 3 [86, 92, 108], the allele-specific PCR-based tests have proven efficient and sensitive in the detection of EGFR mutations. Accordingly, some molecular PCR tests received the U.S. Food and Drug Administration (FDA) approval as "companion diagnostic" tests for NSCLC patients. These include, among others, the Cobas ${ }^{\circledR}$ EGFR Mutation test (Roche) (based on real-time allele-specific PCR with Taqman probes) and the Therascreen ${ }^{\circledR}$ EGFR RGQ PCR kit (Qiagen) (based on allele-specific PCR with Scorpions probes) to identify EGFR mutations. The Cobas ${ }^{\circledR}$ EGFR Mutation test is designed to detect mutations in EGFR exon 19 and the L858R mutation in exon 21. It was approved by the FDA in 2013 following its use in the EURTAC study, the trial that led to the approval of erlotinib as first-line therapy for patients with NSCLC whose tumors harbor an EGFR-activating mutation [86, $90,109]$. Importantly, in November 2015 the Cobas $\AA$ EGFR Mutation Test v2 was also approved by the FDA as a companion diagnostic test for NSCLC using FFPE. This new version of the original test enables an expanded coverage of EGFR mutations (42 mutations) including exon 19 deletions, L858R substitution (exon 21) and the resistance mutation T790M (exon 20). Notably, this test can be used with either plasma cfDNA or tissue samples, and in June 2016, the FDA approved it as a companion diagnostic test for NSCLC using cfDNA samples. In the multicenter, prospective TRIGGER trial, Marchetti et al. demonstrated that the Cobas ${ }^{\circledR}$ EGFR Mutation Test v2 and NGS display comparable sensitivities and specificities for the detection of EGFR mutations in plasma cfDNA and tissue [110]. In addition, the Therascreen ${ }^{\circledR}$ EGFR RGQ PCR kit (Qiagen) covers 29 mutations in the EGFR gene, including exon 19 deletions and the L858R and T790M mutations [109]. In 2013, this test was FDA-approved following its use in the LUX-Lung 3 study that showed increased benefits when lung adenocarcinoma patients with EGFR-activating mutations were treated with the TKI afatinib as first-line treatment when compared to cisplatin plus pemetrexed [108, 109]. Furthermore, highly specific and sensitive methods have recently been developed for the detection of rare tumor mutations in cfDNA and would be of interest for clinical application. These methodologies include BEAMing dPCR, Safe-Sequencing System (SafeSeqS) (digital PCR by sequencing), tagged-amplicon deep sequencing (TAM-seq) and the Cancer Personalized Profiling by deep sequencing (CAPP-seq) [12, 70, 111].

In a clinical setting, deciding how to interpret results from the assays presented here is challenging given that each assay has its own level of detection. For example, levels of detection using ddPCR alone can vary from $0.003 \%$ [95] to $0.04 \%$ [94, 97]. Other PCRbased assays have levels of detection of $0.1 \%$ (PNAclamp) [89] and of 1-2\% (in-house allele-specific PCR) $[93,112]$. Furthermore, clinically relevant and FDA approved tests such as the Cobas ${ }^{\circledR}$ EGFR Mutation Test and the Therascreen ${ }^{\circledR}$ EGFR RGQ PCR test, have reported sensitivities of $0.02 \%$ and $0.05-2 \%$, respectively [89, 110 , 112]. Moreover, different concordance rates between tumor tissue and cfDNA can result from differences in extraction and detection methods, the size of cfDNA fragments, the quantity of cfDNA in the sample, and differences in tumor biology [91]. Therefore, when choosing an assay to use in a clinical setting, extraction methods and the desired limit of detection must be taken into consideration and standardized.

\section{MET mutations}

The mesenchymal-epithelial transition factor $(M E T)$ gene codes for a receptor tyrosine kinase responsible for activation of signaling cascades downstream of SRC homology 2 domain-containing phosphatase 2 (SHP2), PI3K, CRK-like protein (CRKL), among others, and is often involved in oncogenesis in many cancer types, including lung tumors [113]. In several cases, $M E T$ amplification has been associated with resistance to $E G F R$ TKI therapy [114]. More recently, oncogenic splice-site mutations of MET at exon 14 have been discovered and were shown to activate c-MET in patients with NSCLC and SCLC [115-118]. In terms of treatment, MET-directed anti-cancer therapies are currently under preclinical and clinical trials and include c-MET inhibitors (Tivantinib, Cabozantinib and Foretinib), anti-MET antibodies (Onartuzumab), and anti-HGF (as the hepatocyte growth factor is a MET ligand) antibodies (Rilotumumab and Ficlatuzumab) [119]. Furthermore, crizotinib is a dual $A L K / M E T$ inhibitor, presently approved for the treatment of NSCLC patients harboring an $E M L 4-A L K$ fusion. Its 
efficacy has also been reported in some cases of $M E T$ amplification, suggesting its potential interest in $M E T$ targeted therapies [119].

The availability of these therapeutic options fueled screening of activated MET in a broad range of cancer [120]. NGS has been used to detect MET mutations, including exon 14 splice-site mutations that result in exon 14 skipping in patients with lung cancer (Figure 3 ). In a study to characterize $M E T$ mutations across many tumor types, MET exon 14 mutations were detected in $3 \%$ of non-squamous NSCLC cases, mainly adenocarcinomas, were found specifically in older patients and were frequent in early-stage tumors, suggesting their role in lung tumorigenesis [121]. Notably, stage IV NSCLC patients whose tumors exhibited MET exon 14 mutations were more likely to display concurrent MET amplification and c-MET overexpression [121]. Also, using NGS, Frampton et al. found that $M E T$ exon 14 splicing alterations, but not $M E T$ amplification, were often concomitant with the presence of $M D M 2 / C D K 4$ amplifications in solid tumor samples $[122,123]$. Taken together, these results indicate that MET mutations can be found in NSCLC and could aid in diagnosis and in treatment decisions.

Importantly, in two separate case reports, NGS detected the presence of a MET exon 14 splice-site mutation in NSCLC tumor tissue, and in each case report, the patient was treated with the $M E T$ inhibitor crizotinib and showed a partial response or a significant decrease in tumor size [124, 125]. In another study, tumor samples from 178 patients with advanced NSCLC were sequenced using hybrid capture-based NGS. MET exon 14 splice-site mutations were detected in 8 patients, and of the 4 patients who received $M E T$ inhibitors, 3 patients exhibited either complete or partial responses [126]. These case reports and studies highlight the importance of MET sequencing in a clinical setting and the need for further investigation of $M E T$ exon 14 splice-site mutations as possible therapeutic targets in lung cancer.

Interestingly, recent data presented at the 2016 European Lung Cancer Conference (ELCC) highlight the promising use of cfDNA for the detection of $M E T$ exon 14 mutations. Indeed, the digital sequencing-based liquid biopsy-dedicated Guardant 360 test (Guardant Health) has been used for genomic profiling of cfDNA collected from 54 patients with late-stage or recurrent lung adenocarcinoma. This test detects different alterations in 70 cancer-related genes, including MET exon 14 skipping. The data showed an overall concordance rate of $48 \%$ between molecular analyses performed in cfDNA and in tissue, with a higher concordance for EGFR mutations (71\%) (Santos et al., poster presented at 2016 European Lung Cancer Conference). Such studies help pave the way for successful detection of MET exon 14 skipping in liquid biopsies.

Based on recent studies, about 3 to $5 \%$ of NSCLC patients are expected to harbor MET exon 14 skipping, driving cancer progression and metastasis [53, 121, 123, 127]. In the future, NGS will play an essential role in establishing $M E T$ testing for personalized medicine by identifying patients who have $M E T$-driven NSCLC and will benefit from $M E T$ inhibitors. More importantly, plasma cfDNA, which has shown promising results to detect MET exon 14 splice-site mutations, can be evaluated further to monitor the molecular changes upon therapeutic treatment.

\section{CONCLUSIONS}

In the past, lung cancer diagnosis was timeconsuming, costly, and invasive as it involved computer tomography (CT), positron emission tomography (PET), and CT-guided needle biopsies. Moreover, treatment could not meet the specific needs of the individual. With the advent of advanced molecular technologies and the knowledge gained from large-scale sequencing projects, there has been a push for individualized diagnosis and treatment in personalized medicine. By using cfDNA for liquid biopsies and NGS as a platform to analyze mutations found in cfDNA, lung cancer diagnosis can become less invasive and less expensive. Furthermore, treatment can be modified to meet a patient's specific needs, and changes in tumors can be monitored over time. To move forward, several technical improvements and standardization steps need to be considered in order to expedite the use of cell-free DNA and NGS in routine clinical practice.

\section{CONFLICTS OF INTEREST}

The authors have no conflicts of interest to report.

\section{GRANT SUPPORT}

CWB was supported by a Fulbright Grant. VEK and YJK were supported by the PPM program funded by the Ministry for Higher Education and Research (MESR) in Luxembourg.

\section{REFERENCES}

1. Fitzmaurice C, Dicker D, Pain A, Hamavid H, MoradiLakeh M, MacIntyre MF, Allen C, Hansen G, Woodbrook R, Wolfe C, Hamadeh RR, Moore A, Werdecker A, et al. The Global Burden of Cancer 2013. JAMA Oncol. 2015; 1:505-527.

2. Luengo-Fernandez R, Leal J, Gray A, Sullivan R. Economic burden of cancer across the European Union: a populationbased cost analysis. Lancet Oncol. 2013; 14:1165-1174.

3. Mariotto AB, Yabroff KR, Shao Y, Feuer EJ, Brown ML. Projections of the cost of cancer care in the United States: 2010-2020. J Natl Cancer Inst. 2011; 103:117-128. 
4. Bernaudin JF. Molecular characteristics of lung cancer. Bull Cancer. 2010; 97:1323-1335.

5. Derman BA, Mileham KF, Bonomi PD, Batus M, Fidler MJ. Treatment of advanced squamous cell carcinoma of the lung: a review. Transl Lung Cancer Res. 2015; 4:524-532.

6. Mirnezami R, Nicholson J, Darzi A. Preparing for precision medicine. N Engl J Med. 2012; 366:489-491.

7. McDonald ES, Clark AS, Tchou J, Zhang P, Freedman GM. Clinical Diagnosis and Management of Breast Cancer. J Nucl Med. 2016; 57:9s-16s.

8. de Bono JS, Ashworth A. Translating cancer research into targeted therapeutics. Nature. 2010; 467:543-549.

9. Collins FS, Varmus H. A new initiative on precision medicine. N Engl J Med. 2015; 372:793-795.

10. Li T, Kung HJ, Mack PC, Gandara DR. Genotyping and genomic profiling of non-small-cell lung cancer: implications for current and future therapies. J Clin Oncol. 2013; 31:1039-1049.

11. Gonzalez de Castro D, Clarke PA, Al-Lazikani B, Workman P. Personalized cancer medicine: molecular diagnostics, predictive biomarkers, and drug resistance. Clin Pharmacol Ther. 2013; 93:252-259.

12. Diaz LA, Bardelli A. Liquid biopsies: genotyping circulating tumor DNA. J Clin Oncol. 2014; 32:579-586.

13. Leon SA, Shapiro B, Sklaroff DM, Yaros MJ. Free DNA in the serum of cancer patients and the effect of therapy. Cancer Res. 1977; 37:646-650.

14. Jahr S, Hentze H, Englisch S, Hardt D, Fackelmayer FO, Hesch RD, Knippers R. DNA fragments in the blood plasma of cancer patients: quantitations and evidence for their origin from apoptotic and necrotic cells. Cancer Res. $2001 ; 61: 1659-1665$.

15. Fournie GJ, Courtin JP, Laval F, Chale JJ, Pourrat JP, Pujazon MC, Lauque D, Carles P. Plasma DNA as a marker of cancerous cell death. Investigations in patients suffering from lung cancer and in nude mice bearing human tumours. Cancer Lett. 1995; 91:221-227.

16. Stroun M, Lyautey J, Lederrey C, Olson-Sand A, Anker $\mathrm{P}$. About the possible origin and mechanism of circulating DNA apoptosis and active DNA release. Clin Chim Acta. 2001; 313:139-142.

17. Fan HC, Blumenfeld YJ, Chitkara U, Hudgins L, Quake SR. Analysis of the size distributions of fetal and maternal cell-free DNA by paired-end sequencing. Clin Chem. 2010; 56:1279-1286.

18. Bronkhorst AJ, Wentzel JF, Aucamp J, van Dyk E, du Plessis L, Pretorius PJ. Characterization of the cell-free DNA released by cultured cancer cells. Biochim Biophys Acta. 2016; 1863:157-165.

19. Garcia-Olmo DC, Dominguez C, Garcia-Arranz M, Anker P, Stroun M, Garcia-Verdugo JM, Garcia-Olmo D. Cell-free nucleic acids circulating in the plasma of colorectal cancer patients induce the oncogenic transformation of susceptible cultured cells. Cancer Res. 2010; 70:560-567.
20. Trejo-Becerril C, Perez-Cardenas E, Taja-Chayeb L, Anker P, Herrera-Goepfert R, Medina-Velazquez LA, HidalgoMiranda A, Perez-Montiel D, Chavez-Blanco A, CruzVelazquez J, Diaz-Chavez J, Gaxiola M, Duenas-Gonzalez A. Cancer progression mediated by horizontal gene transfer in an in vivo model. PLoS One. 2012; 7:e52754.

21. Paci M, Maramotti S, Bellesia E, Formisano D, Albertazzi L, Ricchetti T, Ferrari G, Annessi V, Lasagni D, Carbonelli C, De Franco S, Brini M, Sgarbi G, et al. Circulating plasma DNA as diagnostic biomarker in non-small cell lung cancer. Lung Cancer. 2009; 64:92-97.

22. Olsson E, Winter C, George A, Chen Y, Howlin J, Tang MH, Dahlgren M, Schulz R, Grabau D, van Westen D, Ferno M, Ingvar C, Rose C, et al. Serial monitoring of circulating tumor DNA in patients with primary breast cancer for detection of occult metastatic disease. EMBO Mol Med. 2015; 7:1034-1047.

23. Shao X, He Y, Ji M, Chen X, Qi J, Shi W, Hao T, Ju S. Quantitative analysis of cell-free DNA in ovarian cancer. Oncol Lett. 2015; 10:3478-3482.

24. Czeiger D, Shaked G, Eini H, Vered I, Belochitski O, Avriel A, Ariad S, Douvdevani A. Measurement of circulating cell-free DNA levels by a new simple fluorescent test in patients with primary colorectal cancer. Am J Clin Pathol. 2011; 135:264-270.

25. Lebofsky R, Decraene C, Bernard V, Kamal M, Blin A, Leroy Q, Rio Frio T, Pierron G, Callens C, Bieche I, Saliou A, Madic J, Rouleau E, et al. Circulating tumor DNA as a non-invasive substitute to metastasis biopsy for tumor genotyping and personalized medicine in a prospective trial across all tumor types. Mol Oncol. 2015; 9:783-790.

26. Janku F, Angenendt P, Tsimberidou AM, Fu S, Naing A, Falchook GS, Hong DS, Holley VR, Cabrilo G, Wheler JJ, Piha-Paul SA, Zinner RG, Bedikian AY, et al. Actionable mutations in plasma cell-free DNA in patients with advanced cancers referred for experimental targeted therapies. Oncotarget. 2015; 6:12809-12821. doi: 10.18632/ oncotarget. 3373 .

27. Birkenkamp-Demtroder K, Nordentoft I, Christensen E, Hoyer S, Reinert T, Vang S, Borre M, Agerbaek M, Jensen JB, Orntoft TF, Dyrskjot L. Genomic Alterations in Liquid Biopsies from Patients with Bladder Cancer. Eur Urol. 2016; 70:75-82.

28. Togneri FS, Ward DG, Foster JM, Devall AJ, Wojtowicz P, Alyas S, Vasques FR, Oumie A, James ND, Cheng KK, Zeegers MP, Deshmukh N, O'Sullivan B, et al. Genomic complexity of urothelial bladder cancer revealed in urinary cfDNA. Eur J Hum Genet. 2016.

29. Frenel JS, Carreira S, Goodall J, Roda D, Perez-Lopez R, Tunariu N, Riisnaes R, Miranda S, Figueiredo I, NavaRodrigues D, Smith A, Leux C, Garcia-Murillas I, et al. Serial Next-Generation Sequencing of Circulating Cell-Free DNA Evaluating Tumor Clone Response To Molecularly Targeted Drug Administration. Clin Cancer Res. 2015; 21:4586-4596. 
30. Sozzi G, Conte D, Mariani L, Lo Vullo S, Roz L, Lombardo C, Pierotti MA, Tavecchio L. Analysis of circulating tumor DNA in plasma at diagnosis and during follow-up of lung cancer patients. Cancer Res. 2001; 61:4675-4678.

31. Jamal-Hanjani M, Wilson GA, Horswell S, Mitter R, Sakarya O, Constantin T, Salari R, Kirkizlar E, Sigurjonsson S, Pelham R, Kareht S, Zimmermann B, Swanton C. Detection of Ubiquitous and Heterogeneous Mutations in Cell-Free DNA from Patients with Early-Stage Non-Small-Cell Lung Cancer. Ann Oncol. 2016; 27:862867.

32. Szpechcinski A, Chorostowska-Wynimko J, Struniawski R, Kupis W, Rudzinski P, Langfort R, Puscinska E, Bielen P, Sliwinski P, Orlowski T. Cell-free DNA levels in plasma of patients with non-small-cell lung cancer and inflammatory lung disease. Br J Cancer. 2015; 113:476-483.

33. Gautschi O, Bigosch C, Huegli B, Jermann M, Marx A, Chasse E, Ratschiller D, Weder W, Joerger M, Betticher DC, Stahel RA, Ziegler A. Circulating deoxyribonucleic Acid as prognostic marker in non-small-cell lung cancer patients undergoing chemotherapy. J Clin Oncol. 2004; 22:4157-4164.

34. Bortolin MT, Tedeschi R, Bidoli E, Furlan C, Basaglia G, Minatel E, Gobitti C, Franchin G, Trovo M, De Paoli P. Cell-free DNA as a prognostic marker in stage I nonsmall-cell lung cancer patients undergoing stereotactic body radiotherapy. Biomarkers. 2015; 20:422-428.

35. Tissot C, Toffart AC, Villar S, Souquet PJ, Merle P, Moro-Sibilot D, Perol M, Zavadil J, Brambilla C, Olivier M, Couraud S. Circulating free DNA concentration is an independent prognostic biomarker in lung cancer. Eur Respir J. 2015; 46:1773-1780.

36. Li BT, Drilon A, Johnson ML, Hsu M, Sima CS, McGinn C, Sugita H, Kris MG, Azzoli CG. A prospective study of total plasma cell-free DNA as a predictive biomarker for response to systemic therapy in patients with advanced nonsmall-cell lung cancers. Ann Oncol. 2016; 27:154-159.

37. Del Re M, Tiseo M, Bordi P, D’Incecco A, Camerini A, Petrini I, Lucchesi M, Inno A, Spada D, Vasile E, Citi V, Malpeli G, Testa E, et al. Contribution of KRAS mutations and c.2369C > T (p.T790M) EGFR to acquired resistance to EGFR-TKIs in EGFR mutant NSCLC: a study on circulating tumor DNA. Oncotarget. 2016; doi: 10.18632/ oncotarget.6957.

38. Lee SM, Park JY, Kim DS. Methylation of TMEFF2 gene in tissue and serum DNA from patients with non-small cell lung cancer. Mol Cells. 2012; 34:171-176.

39. Wang H, Zhang B, Chen D, Xia W, Zhang J, Wang F, Xu J, Zhang Y, Zhang M, Zhang L, Lu Y, Geng Y, Huang $\mathrm{P}$, et al. Real-time monitoring efficiency and toxicity of chemotherapy in patients with advanced lung cancer. Clin Epigenetics. 2015; 7:119.

40. Powrozek T, Krawczyk P, Nicos M, Kuznar-Kaminska B, Batura-Gabryel H, Milanowski J. Methylation of the
DCLK1 promoter region in circulating free DNA and its prognostic value in lung cancer patients. Clin Transl Oncol. 2016; 18:398-404.

41. Wielscher M, Vierlinger K, Kegler U, Ziesche R, Gsur A, Weinhausel A. Diagnostic Performance of Plasma DNA Methylation Profiles in Lung Cancer, Pulmonary Fibrosis and COPD. EBioMedicine. 2015; 2:927-934.

42. Ralla B, Stephan C, Meller S, Dietrich D, Kristiansen G, Jung K. Nucleic acid-based biomarkers in body fluids of patients with urologic malignancies. Crit Rev Clin Lab Sci. 2014; 51:200-231.

43. Lin MT, Mosier SL, Thiess M, Beierl KF, Debeljak M, Tseng LH, Chen G, Yegnasubramanian S, Ho H, Cope L, Wheelan SJ, Gocke CD, Eshleman JR. Clinical validation of KRAS, BRAF, and EGFR mutation detection using nextgeneration sequencing. Am J Clin Pathol. 2014; 141:856866.

44. Luthra R, Chen H, Roy-Chowdhuri S, Singh RR. NextGeneration Sequencing in Clinical Molecular Diagnostics of Cancer: Advantages and Challenges. Cancers. 2015; 7:2023-2036.

45. Meldrum C, Doyle MA, Tothill RW. Next-generation sequencing for cancer diagnostics: a practical perspective. Clin Biochem Rev. 2011; 32:177-195.

46. Margulies M, Egholm M, Altman WE, Attiya S, Bader JS, Bemben LA, Berka J, Braverman MS, Chen YJ, Chen Z, Dewell SB, Du L, Fierro JM, et al. Genome sequencing in microfabricated high-density picolitre reactors. Nature. 2005; 437:376-380.

47. Rothberg JM, Hinz W, Rearick TM, Schultz J, Mileski W, Davey M, Leamon JH, Johnson K, Milgrew MJ, Edwards M, Hoon J, Simons JF, Marran D, et al. An integrated semiconductor device enabling non-optical genome sequencing. Nature. 2011; 475:348-352.

48. Bentley DR, Balasubramanian S, Swerdlow HP, Smith GP, Milton J, Brown CG, Hall KP, Evers DJ, Barnes CL, Bignell HR, Boutell JM, Bryant J, Carter RJ, et al. Accurate whole human genome sequencing using reversible terminator chemistry. Nature. 2008; 456:53-59.

49. Hagemann IS, O’Neill PK, Erill I, Pfeifer JD. Diagnostic yield of targeted next generation sequencing in various cancer types: an information-theoretic approach. Cancer Genet. 2015; 208:441-447.

50. Chevrier S, Arnould L, Ghiringhelli F, Coudert B, Fumoleau P, Boidot R. Next-generation sequencing analysis of lung and colon carcinomas reveals a variety of genetic alterations. Int J Oncol. 2014; 45:1167-1174.

51. Schwaederle M, Elkin SK, Tomson BN, Carter JL, Kurzrock R. Squamousness: Next-generation sequencing reveals shared molecular features across squamous tumor types. Cell Cycle. 2015; 14:2355-2361.

52. The Cancer Genome Atlas Research Network. Comprehensive genomic characterization of squamous cell lung cancers. Nature. 2012; 489:519-525. 
53. The Cancer Genome Atlas Research Network. Comprehensive molecular profiling of lung adenocarcinoma. Nature. 2014; 511:543-550.

54. Vollbrecht C, Werner R, Walter RF, Christoph DC, Heukamp LC, Peifer M, Hirsch B, Burbat L, Mairinger T, Kurt Werner S, Wohlschlaeger J, Mairinger FD. Mutational analysis of pulmonary tumours with neuroendocrine features using targeted massive parallel sequencing: a comparison of a neglected tumour group. Br J Cancer. 2015; 113:1704-1711.

55. Armengol G, Sarhadi VK, Ronty M, Tikkanen M, Knuuttila A, Knuutila S. Driver gene mutations of non-small-cell lung cancer are rare in primary carcinoids of the lung: NGS study by ion Torrent. Lung. 2015; 193:303-308.

56. Zhao X, Wang A, Walter V, Patel NM, Eberhard DA, Hayward MC, Salazar AH, Jo H, Soloway MG, Wilkerson MD, Parker JS, Yin X, Zhang G, et al. Combined Targeted DNA Sequencing in Non-Small Cell Lung Cancer (NSCLC) Using UNCseq and NGScopy, and RNA Sequencing Using UNCqeR for the Detection of Genetic Aberrations in NSCLC. PLoS One. 2015; 10:e0129280.

57. Iwakawa R, Kohno T, Totoki Y, Shibata T, Tsuchihara K, Mimaki S, Tsuta K, Narita Y, Nishikawa R, Noguchi M, Harris CC, Robles AI, Yamaguchi R, et al. Expression and clinical significance of genes frequently mutated in small cell lung cancers defined by whole exome/RNA sequencing. Carcinogenesis. 2015; 36:616-621.

58. Pfarr N, Stenzinger A, Penzel R, Warth A, Dienemann H, Schirmacher P, Weichert W, Endris V. High-throughput diagnostic profiling of clinically actionable gene fusions in lung cancer. Genes Chromosomes Cancer. 2016; 55:30-44.

59. Capelletti M, Dodge ME, Ercan D, Hammerman PS, Park SI, Kim J, Sasaki H, Jablons DM, Lipson D, Young L, Stephens PJ, Miller VA, Lindeman NI, et al. Identification of recurrent FGFR3-TACC3 fusion oncogenes from lung adenocarcinoma. Clin Cancer Res. 2014; 20:6551-6558.

60. Xiong D, Wang Y, Kupert E, Simpson C, Pinney SM, Gaba CR, Mandal D, Schwartz AG, Yang P, de Andrade M, Pikielny C, Byun J, Li Y, et al. A recurrent mutation in PARK2 is associated with familial lung cancer. Am J Hum Genet. 2015; 96:301-308.

61. Li S, Wang L, Ma Z, Ma Y, Zhao J, Peng BO, Qiao Z. Sequencing study on familial lung squamous cancer. Oncol Lett. 2015; 10:2634-2638.

62. Pirker R, Filipits M. Personalized treatment of advanced non-small-cell lung cancer in routine clinical practice. Cancer Metastasis Rev. 2016; 35:141-150.

63. Karnes HE, Duncavage EJ, Bernadt CT. Targeted nextgeneration sequencing using fine-needle aspirates from adenocarcinomas of the lung. Cancer Cytopathol. 2014; 122:104-113.

64. Qiu T, Guo H, Zhao H, Wang L, Zhang Z. Next-generation sequencing for molecular diagnosis of lung adenocarcinoma specimens obtained by fine needle aspiration cytology. Sci
Rep. 2015; 5:11317.

65. Xia S, Huang CC, Le M, Dittmar R, Du M, Yuan T, Guo Y, Wang Y, Wang X, Tsai S, Suster S, Mackinnon AC, Wang L. Genomic variations in plasma cell free DNA differentiate early stage lung cancers from normal controls. Lung Cancer. 2015; 90:78-84.

66. Paweletz CP, Sacher AG, Raymond CK, Alden RS, O’Connell A, Mach SL, Kuang Y, Gandhi L, Kirschmeier P, English JM, Lim LP, Janne PA, Oxnard GR. BiasCorrected Targeted Next-Generation Sequencing for Rapid, Multiplexed Detection of Actionable Alterations in CellFree DNA from Advanced Lung Cancer Patients. Clin Cancer Res. 2016; 22:915-922.

67. Xu S, Lou F, Wu Y, Sun DQ, Zhang JB, Chen W, Ye H, Liu JH, Wei S, Zhao MY, Wu WJ, Su XX, Shi R, et al. Circulating tumor DNA identified by targeted sequencing in advanced-stage non-small cell lung cancer patients. Cancer Lett. 2016; 370:324-331.

68. Vanni I, Coco S, Truini A, Rusmini M, Dal Bello MG, Alama A, Banelli B, Mora M, Rijavec E, Barletta G, Genova C, Biello F, Maggioni C, et al. Next-Generation Sequencing Workflow for NSCLC Critical Samples Using a Targeted Sequencing Approach by Ion Torrent PGM Platform. Int J Mol Sci. 2015; 16:28765-28782.

69. Jeon S, Lee H, Bae K, Yoon KA, Lee ES, Cho Y. Efficient Capture and Isolation of Tumor-Related Circulating CellFree DNA from Cancer Patients Using Electroactive Conducting Polymer Nanowire Platforms. Theranostics. 2016; 6:828-836.

70. Newman AM, Bratman SV, To J, Wynne JF, Eclov NC, Modlin LA, Liu CL, Neal JW, Wakelee HA, Merritt RE, Shrager JB, Loo BW, Jr., Alizadeh AA, et al. An ultrasensitive method for quantitating circulating tumor DNA with broad patient coverage. Nat Med. 2014; 20:548554.

71. Chudziak J, Burt DJ, Mohan S, Rothwell DG, Mesquita B, Antonello J, Dalby S, Ayub M, Priest L, Carter L, Krebs MG, Blackhall F, Dive C, et al. Clinical evaluation of a novel microfluidic device for epitope-independent enrichment of circulating tumour cells in patients with small cell lung cancer. Analyst. 2016; 141:669-678.

72. Buttitta F, Felicioni L, Del Grammastro M, Filice G, Di Lorito A, Malatesta S, Viola P, Centi I, D'Antuono T, Zappacosta R, Rosini S, Cuccurullo F, Marchetti A. Effective assessment of egfr mutation status in bronchoalveolar lavage and pleural fluids by nextgeneration sequencing. Clin Cancer Res. 2013; 19:691-698.

73. Chang F, Li MM. Clinical application of amplicon-based next-generation sequencing in cancer. Cancer Genet. 2014; 206:413-419.

74. Wong SQ, Fellowes A, Doig K, Ellul J, Bosma TJ, Irwin D, Vedururu R, Tan AY, Weiss J, Chan KS, Lucas M, Thomas DM, Dobrovic A, et al. Assessing the clinical value of targeted massively parallel sequencing in a longitudinal, prospective population-based study of cancer patients. $\mathrm{Br}$ 
J Cancer. 2015; 112:1411-1420.

75. Dong L, Wang W, Li A, Kansal R, Chen Y, Chen H, Li X. Clinical Next Generation Sequencing for Precision Medicine in Cancer. Curr Genomics. 2015; 16:253-263.

76. Quail MA, Smith M, Coupland P, Otto TD, Harris SR, Connor TR, Bertoni A, Swerdlow HP, Gu Y. A tale of three next generation sequencing platforms: comparison of Ion Torrent, Pacific Biosciences and Illumina MiSeq sequencers. BMC Genomics. 2012; 13:341.

77. Rhoads A, Au KF. PacBio Sequencing and Its Applications. Genomics Proteomics Bioinformatics. 2015; 13:278-289.

78. Hinrichs JW, van Blokland WT, Moons MJ, Radersma RD, Radersma-van Loon JH, de Voijs CM, Rappel SB, Koudijs MJ, Besselink NJ, Willems SM, de Weger RA. Comparison of next-generation sequencing and mutationspecific platforms in clinical practice. Am J Clin Pathol. 2015; 143:573-578.

79. Li X, Buckton AJ, Wilkinson SL, John S, Walsh R, Novotny T, Valaskova I, Gupta M, Game L, Barton PJ, Cook SA, Ware JS. Towards clinical molecular diagnosis of inherited cardiac conditions: a comparison of bench-top genome DNA sequencers. PLoS One. 2013; 8:e67744.

80. Tuononen K, Maki-Nevala S, Sarhadi VK, Wirtanen A, Ronty M, Salmenkivi K, Andrews JM, Telaranta-Keerie AI, Hannula S, Lagstrom S, Ellonen P, Knuuttila A, Knuutila S. Comparison of targeted next-generation sequencing (NGS) and real-time PCR in the detection of EGFR, KRAS, and BRAF mutations on formalin-fixed, paraffin-embedded tumor material of non-small cell lung carcinoma-superiority of NGS. Genes Chromosomes Cancer. 2013; 52:503-511.

81. Ragazzi M, Tamagnini I, Bisagni A, Cavazza A, Pagano M, Baldi L, Boni C, Cantile F, Barbieri F, Nicoli D, Sartori G, de Biase D, Gardini G, et al. Diamond: immunohistochemistry versus sequencing in EGFR analysis of lung adenocarcinomas. J Clin Pathol. 2015; 0:18.

82. Drilon A, Wang L, Arcila ME, Balasubramanian S, Greenbowe JR, Ross JS, Stephens P, Lipson D, Miller VA, Kris MG, Ladanyi M, Rizvi NA. Broad, Hybrid CaptureBased Next-Generation Sequencing Identifies Actionable Genomic Alterations in Lung Adenocarcinomas Otherwise Negative for Such Alterations by Other Genomic Testing Approaches. Clin Cancer Res. 2015; 21:3631-3639.

83. Carcereny E, Moran T, Capdevila L, Cros S, Vila L, de Los Llanos Gil M, Remon J, Rosell R. The epidermal growth factor receptor (EGRF) in lung cancer. Transl Respir Med. 2015; 3:1.

84. Paz-Ares L, Soulieres D, Moecks J, Bara I, Mok T, Klughammer B. Pooled analysis of clinical outcome for EGFR TKI-treated patients with EGFR mutation-positive NSCLC. J Cell Mol Med. 2014; 18:1519-1539.

85. Zhou C, Wu YL, Chen G, Feng J, Liu XQ, Wang C, Zhang S, Wang J, Zhou S, Ren S, Lu S, Zhang L, Hu C, et al. Erlotinib versus chemotherapy as first-line treatment for patients with advanced EGFR mutation-positive non-smallcell lung cancer (OPTIMAL, CTONG-0802): a multicentre, open-label, randomised, phase 3 study. Lancet Oncol. 2011; 12:735-742.

86. Rosell R, Carcereny E, Gervais R, Vergnenegre A, Massuti B, Felip E, Palmero R, Garcia-Gomez R, Pallares C, Sanchez JM, Porta R, Cobo M, Garrido P, et al. Erlotinib versus standard chemotherapy as first-line treatment for European patients with advanced EGFR mutation-positive non-small-cell lung cancer (EURTAC): a multicentre, open-label, randomised phase 3 trial. Lancet Oncol. 2012; 13:239-246.

87. Yang JC, Srimuninnimit V, Ahn MJ, Lin CC, Kim SW, Tsai CM, Mok T, Orlando M, Puri T, Wang X, Park K. First-Line Pemetrexed plus Cisplatin followed by Gefitinib Maintenance Therapy versus Gefitinib Monotherapy in East Asian Never-Smoker Patients with Locally Advanced or Metastatic Nonsquamous Non-Small Cell Lung Cancer: Final Overall Survival Results from a Randomized Phase 3 Study. J Thorac Oncol. 2016; 11:370-379.

88. Pao W, Miller VA, Politi KA, Riely GJ, Somwar R, Zakowski MF, Kris MG, Varmus H. Acquired resistance of lung adenocarcinomas to gefitinib or erlotinib is associated with a second mutation in the EGFR kinase domain. PLoS Med. 2005; 2:e73.

89. Pasquale R, Fenizia F, Esposito Abate R, Sacco A, Esposito C, Forgione L, Rachiglio AM, Bevilacqua S, Montanino A, Franco R, Rocco G, Botti G, Denis MG, et al. Assessment of high-sensitive methods for the detection of EGFR mutations in circulating free tumor DNA from NSCLC patients. Pharmacogenomics. 2015; 16:1135-1148.

90. Karachaliou N, Mayo-de las Casas C, Queralt C, de Aguirre I, Melloni B, Cardenal F, Garcia-Gomez R, Massuti B, Sanchez JM, Porta R, Ponce-Aix S, Moran T, Carcereny E, et al. Association of EGFR L858R Mutation in Circulating Free DNA With Survival in the EURTAC Trial. JAMA Oncol. 2015; 1:149-157.

91. Goto K, Ichinose Y, Ohe Y, Yamamoto N, Negoro S, Nishio K, Itoh Y, Jiang H, Duffield E, McCormack R, Saijo N, Mok T, Fukuoka M. Epidermal growth factor receptor mutation status in circulating free DNA in serum: from IPASS, a phase III study of gefitinib or carboplatin/ paclitaxel in non-small cell lung cancer. J Thorac Oncol. 2012; 7:115-121.

92. Mok TS, Wu YL, Thongprasert S, Yang CH, Chu DT, Saijo N, Sunpaweravong P, Han B, Margono B, Ichinose Y, Nishiwaki Y, Ohe Y, Yang JJ, et al. Gefitinib or carboplatin-paclitaxel in pulmonary adenocarcinoma. N Engl J Med. 2009; 361:947-957.

93. Guo K, Zhang Z, Han L, Han J, Wang J, Zhou Y, Liu H, Tong L, Li X, Yan X. Detection of epidermal growth factor receptor mutation in plasma as a biomarker in Chinese patients with early-stage non-small cell lung cancer. Onco Targets Ther. 2015; 8:3289-3296.

94. Zhu G, Ye X, Dong Z, Lu YC, Sun Y, Liu Y, McCormack 
R, Gu Y, Liu X. Highly Sensitive Droplet Digital PCR Method for Detection of EGFR-Activating Mutations in Plasma Cell-Free DNA from Patients with Advanced NonSmall Cell Lung Cancer. J Mol Diagn. 2015; 17:265-272.

95. Lee JY, Qing X, Xiumin W, Yali B, Chi S, Bak SH, Lee HY, Sun JM, Lee SH, Ahn JS, Cho EK, Kim DW, Kim $\mathrm{HR}$, et al. Longitudinal monitoring of EGFR mutations in plasma predicts outcomes of NSCLC patients treated with EGFR TKIs: Korean Lung Cancer Consortium (KLCC12-02). Oncotarget. 2016; 7:6984-6993. doi:10.18632/ oncotarget.6874.

96. Que D, Xiao H, Zhao B, Zhang X, Wang Q, Xiao H, Wang G. EGFR mutation status in plasma and tumor tissues in non-small cell lung cancer serves as a predictor of response to EGFR-TKI treatment. Cancer Biol Ther. 2016; 17:320327.

97. Yang X, Zhuo M, Ye X, Bai H, Wang Z, Sun Y, Zhao J, An T, Duan J, Wu M, Wang J. Quantification of mutant alleles in circulating tumor DNA can predict survival in lung cancer. Oncotarget. 2016; 7:20810-20824. doi:10.18632/ oncotarget.8021.

98. Ishii H, Azuma K, Sakai K, Kawahara A, Yamada K, Tokito T, Okamoto I, Nishio K, Hoshino T. Digital PCR analysis of plasma cell-free DNA for non-invasive detection of drug resistance mechanisms in EGFR mutant NSCLC: Correlation with paired tumor samples. Oncotarget. 2015; 6:30850-30858. doi:10.18632/oncotarget.5068.

99. Sacher AG, Paweletz C, Dahlberg SE, Alden RS, O'Connell A, Feeney N, Mach SL, Janne PA, Oxnard GR. Prospective Validation of Rapid Plasma Genotyping for the Detection of EGFR and KRAS Mutations in Advanced Lung Cancer. JAMA Oncol. 2016.

100. Thress KS, Brant R, Carr TH, Dearden S, Jenkins S, Brown H, Hammett T, Cantarini M, Barrett JC. EGFR mutation detection in ctDNA from NSCLC patient plasma: A crossplatform comparison of leading technologies to support the clinical development of AZD9291. Lung Cancer. 2015; 90:509-515.

101. Oxnard GR, Thress KS, Alden RS, Lawrance R, Paweletz C, Cantarini M, Yang J, Barrett JC, Janne PA. Association Between Plasma Genotyping and Outcomes of Treatment with Osimertinib (AZD9291) in Advanced Non-Small-Cell Lung Cancer. J Clin Oncol. 2016.

102. Thress KS, Paweletz CP, Felip E, Cho BC, Stetson D, Dougherty B, Lai Z, Markovets A, Vivancos A, Kuang Y, Ercan D, Matthews SE, Cantarini M, et al. Acquired EGFR C797S mutation mediates resistance to AZD9291 in nonsmall cell lung cancer harboring EGFR T790M. Nat Med. $2015 ; 21: 560-562$

103. Masago K, Fujita S, Muraki M, Hata A, Okuda C, Otsuka K, Kaji R, Takeshita J, Kato R, Katakami N, Hirata Y. Nextgeneration sequencing of tyrosine kinase inhibitor-resistant non-small-cell lung cancers in patients harboring epidermal growth factor-activating mutations. BMC Cancer. 2015; 15:908.
104. Kim EY, Cho EN, Park HS, Hong JY, Lim S, Youn JP, Hwang SY, Chang YS. Compound EGFR mutation is frequently detected with co-mutations of actionable genes and associated with poor clinical outcome in lung adenocarcinoma. Cancer Biol Ther. 2016:1-9.

105. Liu X, Lu Y, Zhu G, Lei Y, Zheng L, Qin H, Tang C, Ellison G, McCormack R, Ji Q. The diagnostic accuracy of pleural effusion and plasma samples versus tumour tissue for detection of EGFR mutation in patients with advanced non-small cell lung cancer: comparison of methodologies. J Clin Pathol. 2013; 66:1065-1069.

106. Uchida J, Kato K, Kukita Y, Kumagai T, Nishino K, Daga H, Nagatomo I, Inoue T, Kimura M, Oba S, Ito Y, Takeda K, Imamura F. Diagnostic Accuracy of Noninvasive Genotyping of EGFR in Lung Cancer Patients by Deep Sequencing of Plasma Cell-Free DNA. Clin Chem. 2015; 61:1191-1196.

107. Sundaresan TK, Sequist LV, Heymach JV, Riely GJ, Janne PA, Koch WH, Sullivan JP, Fox DB, Maher R, Muzikansky A, Webb A, Tran HT, Giri U, et al. Detection of T790M, the Acquired Resistance EGFR Mutation, by Tumor Biopsy versus Noninvasive Blood-Based Analyses. Clin Cancer Res. 2016; 22:1103-1110.

108. Sequist LV, Yang JC, Yamamoto N, O’Byrne K, Hirsh V, Mok T, Geater SL, Orlov S, Tsai CM, Boyer M, Su WC, Bennouna J, Kato T, et al. Phase III study of afatinib or cisplatin plus pemetrexed in patients with metastatic lung adenocarcinoma with EGFR mutations. J Clin Oncol. 2013; 31:3327-3334.

109. Khoo C, Rogers TM, Fellowes A, Bell A, Fox S. Molecular methods for somatic mutation testing in lung adenocarcinoma: EGFR and beyond. Transl Lung Cancer Res. 2015; 4:126-141.

110. Marchetti A, Palma JF, Felicioni L, De Pas TM, Chiari R, Del Grammastro M, Filice G, Ludovini V, Brandes AA, Chella A, Malorgio F, Guglielmi F, De Tursi M, et al. Early Prediction of Response to Tyrosine Kinase Inhibitors by Quantification of EGFR Mutations in Plasma of NSCLC Patients. J Thorac Oncol. 2015; 10:1437-1443.

111. Alix-Panabieres C, Pantel K. Clinical Applications of Circulating Tumor Cells and Circulating Tumor DNA as Liquid Biopsy. Cancer Discov. 2016; 6:479-491.

112. Vallee A, Le Loupp AG, Denis MG. Efficiency of the Therascreen(R) RGQ PCR kit for the detection of EGFR mutations in non-small cell lung carcinomas. Clin Chim Acta. 2014; 429:8-11.

113. Gherardi E, Birchmeier W, Birchmeier C, Vande Woude G. Targeting MET in cancer: rationale and progress. Nat Rev Cancer. 2012; 12:89-103.

114. Cheng H, Shcherba M, Kandavelou K, Liang Y, Liu H, Perez-Soler R. Emerging drugs for squamous cell lung cancer. Expert Opin Emerg Drugs. 2015; 20:149-160.

115. Kong-Beltran M, Seshagiri S, Zha J, Zhu W, Bhawe K, Mendoza N, Holcomb T, Pujara K, Stinson J, Fu L, Severin 
C, Rangell L, Schwall R, et al. Somatic mutations lead to an oncogenic deletion of met in lung cancer. Cancer Res. 2006; 66:283-289.

116. Ma PC, Kijima T, Maulik G, Fox EA, Sattler M, Griffin JD, Johnson BE, Salgia R. c-MET mutational analysis in small cell lung cancer: novel juxtamembrane domain mutations regulating cytoskeletal functions. Cancer Res. 2003; 63:6272-6281.

117. Ma PC, Jagadeeswaran R, Jagadeesh S, Tretiakova MS, Nallasura V, Fox EA, Hansen M, Schaefer E, Naoki K, Lader A, Richards W, Sugarbaker D, Husain AN, et al. Functional expression and mutations of c-Met and its therapeutic inhibition with SU11274 and small interfering RNA in non-small cell lung cancer. Cancer Res. 2005; 65:1479-1488.

118. Tong JH, Yeung SF, Chan AW, Chung LY, Chau SL, Lung RW, Tong CY, Chow C, Tin EK, Yu YH, Li H, Pan Y, Chak WP, et al. MET amplification and exon 14 splice site mutation define unique molecular subgroups of Non-small Cell Lung Carcinoma with poor prognosis. Clin Cancer Res. 2016; 22:OF1-OF9.

119. Perez-Ramirez C, Canadas-Garre M, Jimenez-Varo E, Faus-Dader MJ, Calleja-Hernandez MA. MET: a new promising biomarker in non-small-cell lung carcinoma. Pharmacogenomics. 2015; 16:631-647.

120. Zenali M, deKay J, Liu Z, Hamilton S, Zuo Z, Lu X, Bakkar R, Mills G, Broaddus R. Retrospective Review of MET Gene Mutations. Oncoscience. 2015; 2:533-541. doi:10.18632/oncoscience.161.

121. Awad MM, Oxnard GR, Jackman DM, Savukoski DO, Hall D, Shivdasani P, Heng JC, Dahlberg SE, Janne PA, Verma S, Christensen J, Hammerman PS, Sholl LM. MET Exon 14 Mutations in Non-Small-Cell Lung Cancer Are Associated With Advanced Age and Stage-Dependent MET Genomic Amplification and c-Met Overexpression. J Clin Oncol. 2016; 34:721-730.
122. Frampton GM, Fichtenholtz A, Otto GA, Wang K, Downing SR, He J, Schnall-Levin M, White J, Sanford EM, An P, Sun J, Juhn F, Brennan K, et al. Development and validation of a clinical cancer genomic profiling test based on massively parallel DNA sequencing. Nat Biotechnol. 2013; 31:1023-1031.

123. Frampton GM, Ali SM, Rosenzweig M, Chmielecki J, Lu X, Bauer TM, Akimov M, Bufill JA, Lee C, Jentz D, Hoover $\mathrm{R}$, Ou SH, Salgia R, et al. Activation of MET via diverse exon 14 splicing alterations occurs in multiple tumor types and confers clinical sensitivity to MET inhibitors. Cancer Discov. 2015; 5:850-859.

124. Lee C, Usenko D, Frampton GM, McMahon C, Ali SM, Weiss J. MET 14 Deletion in Sarcomatoid Non-Small-Cell Lung Cancer Detected by Next-Generation Sequencing and Successfully Treated with a MET Inhibitor. J Thorac Oncol. 2015; 10:e113-114.

125. Jenkins RW, Oxnard GR, Elkin S, Sullivan EK, Carter JL, Barbie DA. Response to Crizotinib in a Patient With Lung Adenocarcinoma Harboring a MET Splice Site Mutation. Clin Lung Cancer. 2015; 16:e101-104.

126. Paik PK, Drilon A, Fan PD, Yu H, Rekhtman N, Ginsberg MS, Borsu L, Schultz N, Berger MF, Rudin CM, Ladanyi M. Response to MET inhibitors in patients with stage IV lung adenocarcinomas harboring MET mutations causing exon 14 skipping. Cancer Discov. 2015; 5:842-849.

127. Heist RS, Shim HS, Gingipally S, Mino-Kenudson M, Le L, Gainor JF, Zheng Z, Aryee M, Xia J, Jia P, Jin H, Zhao Z, Pao W, et al. MET Exon 14 Skipping in Non-Small Cell Lung Cancer. Oncologist. 2016; 21:481-486. 